\title{
Dealing with Water Conflicts: A Comprehensive Review of MCDM Approaches to Manage Freshwater Ecosystem Services
}

\author{
Mónica de Castro-Pardo ${ }^{1, *}$, Pascual Fernández Martínez ${ }^{2}$, Amelia Pérez Zabaleta ${ }^{3}$ and João C. Azevedo ${ }^{4}$ (D) \\ 1 Department of Financial Economics and Actuarial and Statistics-Statistics and Operational Research, \\ Campus of Somosaguas, Complutense University of Madrid, Pozuelo de Alarcón, 28223 Madrid, Spain \\ 2 Department of Applied Economics I and History and Economic Institutions, UNESCO UNED-URJC Chair \\ in Water and Peace, URJC, Faculty of Law and Social Sciences, Campus of Vicálvaro, Universidad Rey \\ Juan Carlos, Tulipan, Móstoles, 28933 Madrid, Spain; pascual.fernandez@urjc.es \\ 3 Department of Applied Economics, UNESCO UNED-URJC Chair in Water and Peace, UNED, Calle Bravo \\ Murillo 38, 28015 Madrid, Spain; aperez@cee.uned.es \\ 4 Centro de Investigação de Montanha, Campus de Santa Apolónia, Instituto Politécnico de Bragança, \\ 5300-253 Bragança, Portugal; jazevedo@ipb.pt \\ * Correspondence: monica.decastro@ucm.es
}

check for

updates

Citation: de Castro-Pardo, M.; Fernández Martínez, P.; Pérez

Zabaleta, A.; Azevedo, J.C. Dealing with Water Conflicts: A

Comprehensive Review of MCDM Approaches to Manage Freshwater Ecosystem Services. Land 2021, 10, 469. https://doi.org/10.3390/ land10050469

Academic Editor: Eva Papastergiadou

Received: 25 March 2021

Accepted: 22 April 2021

Published: 30 April 2021

Publisher's Note: MDPI stays neutral with regard to jurisdictional claims in published maps and institutional affiliations.

Copyright: (c) 2021 by the authors. Licensee MDPI, Basel, Switzerland. This article is an open access article distributed under the terms and conditions of the Creative Commons Attribution (CC BY) license (https:// creativecommons.org/licenses/by/ $4.0 /)$.

\begin{abstract}
This paper presents a comprehensive review of the application of Multiple-Criteria Decision-Making (MCDM) approaches exclusively to water-related freshwater ecosystem services. MCDM analysis has been useful in solving conflicts and it works well in this framework, given the serious conflicts historically associated with water use and the protection of freshwater ecosystems around the world. In this study, we present a review of 150 papers that proposed the use of MCDMbased methods for the social, economic, or ecological planning and management of water ecosystem services over the period 2000-2020. The analysis accounts for six elements: ecosystem service type, method, participation, biogeographical realm, waterbody type, and problem to solve. A Chi-square test was used to identify dependence between these elements. Studies involving the participation of stakeholder groups adopted an integrated approach to analysing sustainable water management, considering provisioning, regulating, and cultural services. However, such studies have been in decline since 2015, in favour of non-participatory studies that were strictly focused on ecological and provisioning issues. Although this reflects greater concern for the health of freshwater ecosystems, it is a long way removed from the essence of ecosystem services, which entails an integrated approach to the interrelationships between hydrology, landscapes, ecology, and humans.
\end{abstract}

Keywords: Multiple-Criteria Decision-Making; water; ecosystem services; conflicts; freshwater ecosystems; stakeholders; protected areas

\section{Introduction}

Freshwater is vital for the functioning of all terrestrial ecosystems, for the flora and fauna that make up those ecosystems, and, of course, for humans. Humanity depends on water not only for drinking, but mostly for food production, industry, waste treatment, energy, and transport, to give just a few examples [1]. Hoekstra and Wiedmann [2] estimated that humans annually consume between 1000 and 1700 billion $\mathrm{m}^{3}$ of the world's surface or groundwater resources per year; that is, through direct or indirect water use, between $22 \%$ and $150 \%$ of the annual global freshwater supply is consumed.

From an ecological perspective, water is an integral component of all ecosystems and their functioning and, thus, is key to ensuring ecosystem health and biodiversity. However, the sensitivity of freshwater ecosystems to a range of threat factors, including climate change, makes water ecosystem services especially vulnerable [3]. Freshwater ecosystems make a disproportionate contribution to global biological richness; however, freshwater species are among those at the greatest risk of extinction [4]. 
Water resources are an issue of major interest and concern for governments and international institutions. Faced with the prospect of billions of people experiencing serious water shortages and subsequent food shortages, there is a need for urgent strategic action on water resources management. Two billion people currently live in countries with high water stress, and it is estimated that, by 2030, as many as 700 million people could be displaced by intense water scarcity [5]. One of the most powerful international attempts to address this serious humanitarian problem is the 2030 Agenda for Sustainable Development and its 17 Sustainable Development Goals (SDG) [6]. Specifically, SDG-6 focus is to "Ensure availability and sustainable management of water and sanitation for all". This target broadly encompasses all aspects of both the water cycle and sanitation systems, and it is designed to be cross-cutting, such that it can contribute to the achievement of other SDGs, particularly in the areas of the environment, health, economy and education.

The current global freshwater crisis threatens the present and future supply of water as a resource for human beings. Although about $70 \%$ of the earth's surface is covered with water, only $2.5 \%$ of it is freshwater that is suitable for human consumption. Most of that freshwater is trapped in glaciers or icefields; as such, less than $1 \%$ of the world's water is freshwater accessible in liquid form. In turn, of this small percentage, most of the water is found flowing underground, in groundwater reserves, while easily-accessible surface water sources, such as rivers or lakes, account for only a fraction of it. This small proportion of freshwater is the driving force of human health, the global economy, and the wellbeing of societies in the broadest sense. Unfortunately, the world has not succeeded in ensuring the sustainable management of its water resources. Over the past century, freshwater came under increasing pressure as withdrawal rates increased almost sixfold. By 2014, the average global availability of renewable freshwater resources had dropped to less than $6000 \mathrm{~m}^{3}$ per person per year, a sharp fall of about $40 \%$ since the 1970 s. Moreover, freshwater resources are unevenly distributed throughout the world and they are affected by strong seasonality; as global demand for water continues to grow (by approximately $1 \%$ annually), available resources are further depleted [7]. This crisis has promoted the need for the development of a water-oriented circular economy and the optimization of water resources use [8,9] with the end goal of preservation of water resources.

The importance and vulnerability of freshwater has prompted growing concern and an interest in its analysis from the scientific community, as well as impelling international institutions to protect freshwater ecological systems. The Ramsar Convention, for example, is one of the most notable initiatives aimed at protecting wetlands. Adopted in 1971, it is the longest-standing treaty that seeks to preserve wetlands and aquatic bird species, and it has been responsible for the establishment of the world's largest network of protected areas [10]. The European Union Water Framework Directive (2000/60/EC; 22 December 2000, OJ L 327) provides a guide for the New European water policy. The novelty of the new framework is the integrated approach that it follows in opposition to fragmented water policy initiatives in the past, based on key aims, such as "expanding the scope of water protection to all waters, surface waters and groundwater", "achieving "good status" for all waters by a set deadline", "water management based on river basins", "combined approach" of emission limit values and quality standards", "getting the prices right", "getting the citizen involved more closely", and "streamlining legislation".

Large watercourses cover different territories, and they are often transboundary, involving different conservation and use objectives, different regulations, and different stakeholders with conflicting interests. As such, their integrated management is extremely complex. Many protected areas around the world (more than 100,000) include aquatic ecosystems, some of which are specifically protected as freshwater ecosystems, but they are often supplied by rivers outside the limits of the protected areas [11].

Planning for such areas is extremely difficult at the operational level, even within the same country. Implementing an environmental conservation programme for freshwater requires the cooperation of multiple stakeholder groups, which often span multiple ecosystems. The complexity increases substantially when the management involves multiple 
jurisdictions or countries. Although there is international regulation governing the protection and use of transboundary watercourses and international lakes (e.g, "The 1992 UNECE Convention on the Protection and Use of Transboundary Watercourses and International Lakes and the EU Water Framework), as well as specific bilateral cooperation agreements, at the operational level, stakeholder groups must also decide on upkeep, enforcement, and assessment programmes [12], meaning that the decisions made are not isolated events but rather part of an ongoing decision-making process over time.

The scarcity of water resources, the protection of many aquatic ecosystems, and the complexity associated with the management of large watercourses have traditionally provoked fierce conflicts that are linked to their management. These disputes can block decision-making processes and even trigger armed clashes between countries [13]. That said, some studies have shown that actively involving stakeholders in decision-making processes can mitigate these problems and make it possible to work towards acceptable solutions [14]. Against this background, Multiple-Criteria Decision-Making (MCDM) methods have proven to be extremely useful for conflict management; in particular, they have been widely used for natural resource management [15]. Research on the development and use of MCDM methods to improve decision-making processes that are related to forestry has been very prolific. Kaya et al. [16], Diaz-Balteiro et al. [17], and Nordstrom et al. [18] are only some examples of this trend. Although these studies addressed the full range of ecosystem services provided, including freshwater ecosystem services, to date only a few reviews focused exclusively on the use of MCDM in water resources management have been conducted. Hajkowicz and Collins [19] reviewed 113 articles published between 1973 and 2005 and Herath [20] conducted a review of 89 articles relating to this topic published between 1975 and 2009.

In regard to water, MCDM approaches are used when the analysis incorporates multiple perspectives in order to reach a single decision relating to water management [21]. The capacity of MCDM analysis to assist in conflict resolution between stakeholder's groups is primarily due to its transparency. All parties must specifically express their preferences through a structured process, which makes it possible to identify areas of agreement and disagreement and ultimately manage conflicts [22]. This analysis of alternatives can be carried out by involving the different stakeholders, experts, or institutional/governmental agents (water negotiators), or by simulating different alternatives through stochastic processes. In any case, the opposition and interrelation of different criteria and alternatives give rise to a wide-ranging, complex workspace, where multiple conflicting positions are involved in a single decision-making process.

This framework is well suited to the planning and management of Freshwater Ecosystem Services (FES). Understanding FES requires an integrated view of the interrelationships between hydrology and ecology as well as the landscape. It also calls for a contextualization of how water influences human livelihoods and wellbeing, as well as how the ecosystems themselves are affected by human activities. In order to develop efficient, sustainable decision-making processes, a comprehension of these complex relationships is needed [1].

This article presents a review of 150 current articles covering the application of MCDM with three novel aspects: a focus on water as source of ecosystem services; a focus on natural freshwater ecosystems, the majority of them protected; and, an orientation of the discussion towards conflict resolution and stakeholder participation in decision-making processes. The objective of this review is to describe the use of MCDM techniques in FES planning and management, with a particular focus on conflict management. The aim of carrying out a systematic review is to collect all of the the empirical evidence that meets the pre-specified criteria above, in order to answer several research questions.

\section{Methods}

Bias is minimised by using explicit and systematic methods when reviewing articles [23]. The main advantage of systematic reviews is that they allow the researcher to determine whether an effect remains constant across various different studies, or to find 
out whether the type of study or sample level have an effect on the phenomenon under study [23].

The present review was conducted following the six steps proposed by Templier and Paré [24]: (i) formulating the research question and objective(s), (ii) searching the extant literature, screening for inclusion, assessing the quality of primary studies, (iii) extracting data, and (iv) analysing data.

\subsection{Formulating the Research Questions and Objectives}

The objective of this review is to characterise the use of MCDM techniques in FES planning and management, with a particular focus on conflict management. We addressed specifically the following research questions: (i) how have studies on MCDM applied to FES change over time?; (ii) how collaborative MCDM has been used to solve decisional problems?; (iii) how has stakeholders involvement in water decision-making processes changed over time?; (iv) what MCDM methods have been applied the most to deal with FES?; and, (v) how have these methods been used to solve different types of problems?

\subsection{Searching the Extant Literature, Screening for Inclusion and Assessing the Quality of Primary Studies}

The search of the literature was performed on the Web of Science (WoS) platform. As such, the only publications included in the search are those from journals indexed in the Journal Citation Report (JCR), thus ensuring the quality of the articles. Book chapters were not included in the queries. The articles were then screened to only select those in where water was analysed from an ecosystem perspective, discarding any articles oriented towards industrial uses of water or the improvement of artificial processes. The keywords used in the selections process included "water" and "ecosystem services" and "MCDM" or "multiple-criteria decision making" and "freshwater" or "water management" and "protected areas". Only articles that were published between 2000 and 2020 were selected. The analysis has been structured by grouping the publication years into four intervals: 2000-2004, 2005-2009, 2010-2014, and 2015-2020.

\subsection{Extracting Data}

Selected papers were classified according to the following categories in each of the six criteria (Ecosystem services, MCDM method, Participation, Biogeography, Waterbody type, and Problem):

- Ecosystem services class:

FES were categorised according to the Millennium Assessment (MA) [25] classification in provisioning, regulating, cultural, and supporting classes.

Provisioning (PROV): refers to water as a resource for human consumption;

Regulating (REG): refers to the ability of freshwater ecosystems to regulate nutrient cycles, atmospheric regulation and control of natural disasters, such as floods;

Cultural (CULT): refers to the recreational capacity of these ecosystems;

Supporting (SUPPORT): refers to the capacity of ecosystems to maintain their structure and functioning, including biodiversity.

- $\quad$ MCDM method:

Methods comprise eight classes:

Distances (DIS): distance-based methods, such as GP or TOPSIS methods, are based on the minimization of the distance between an alternative and one or several reference points that represent good preferential properties [17];

Fuzzy (FUZ): covers the articles that have used fuzzy sets, fuzzy functions, or fuzzy numbers rather than crisp numbers, approaches with a concrete mathematical structure dealing with the imprecision of the information [26];

Hierarchical (HIER): this group includes methods based on AHP or ANP, working with pairwise comparisons to quantify subjective information, such as preferences 
of decision-makers, and calculate relative importance (weights) of criteria and alternatives [27];

Mixed (MIX): hybrid models where no one type of method has particular prominence, but rather all are similarly important in the decision-making process. Ortiz-Urbina et al. [28] emphasised the proliferation of these methods in the last few decades;

Outranking (OUT): outranking methods such as the different versions of PROMETHEE or ELECTRE, based on the idea that alternative $X$ outranks alternative $Y$ if alternative $X$ is at least as good as alternative $Y$, according to concordance and discordant concepts [29,30];

Soft (SOFT): non-structured MCDM methods, such as discussion groups, workshops, or various kinds of collaborative processes based on qualitative analyses [31];

Utility (UT): methods based on utility and value functions, assigning a cardinal value to each alternative considering simultaneously several criteria within a risk (utility) or no risk (value) context [32];

Other methods (Other): those not included in the previous groups.

- Participation:

The participatory approach employed has been assessed according to the extent to which all stakeholders are involved, only experts or institutional/governmental actors, or none of the above. Three groups have thus been identified: non-participatory (NO), experts (EXP), and stakeholders (YES).

\section{- Biogeography:}

This element has been analysed at the level of country and biogeographic realm, referring to the seven biogeographic divisions of the planet: Afrotropical (AFRO), Antarctic (AN), Australasia (AUS), Indomalaya (INDO), Nearctic (NEAR), Neotropical (NE), and Paleartic (PA) [33]. In cases the origin of the study was not indicated the publication was classified as Not identified (NI).

- Waterbody type:

The type of waterbody studied has been classified into five categories: estuary, groundwater, lake, river, and wetland. Although estuaries are not freshwater ecosystems, as their waters have some degree of salinity depending on the site, they are included in this study because they represent the transition between freshwater and marine ecosystems, and their management is still subject to conflict. Many studies do not analyse a single type of aquatic ecosystem, since it is very difficult to completely separate the interlacing subsystems that make up river networks. Rivers and lakes are often interconnected, and some studies have taken a comprehensive approach to analysing them. Similarly, in some river courses, it can be difficult to distinguish between estuaries and wetlands. For this reason, in the present review, the classification is based on the predominant type under analysis, unless it is specified that the analysis focuses on a river system.

\section{- Problem:}

The problem to be solved refers to the objective of the analysis conducted in the publications. Seven problem types have been identified:

Allocation (ALLOC): allocation and distribution of water as a resource; papers included in this group involve studies analysing best water sources and optimization of water resources distribution to population;

Conservation (CON): solutions to problems related to the conservation of sites and habitats and the survival of species. All of the studies are oriented to the improvement or maintenance of the actual condition of ecosystems;

Flood water analysis (FLOOD): analysis of water flows from river systems and freshwater ecosystems and the associated risks;

Impact/vulnerability assessment (IMPACT-VUL): the articles included in this group focus on measuring and evaluating the impact of human actions on the waterbody under study and assessing its vulnerability. Some also undertake an assessment of water quality; 
Management (MAN): water resources planning and management from a broad perspective, excluding articles dealing specifically with the topics covered in the other classes;

Restoration (RESTOR): restoration of river systems and freshwater ecosystems;

Tourism (TOUR): issues related to tourism management in freshwater ecosystems and analysis of suitability of these sites for recreation.

\subsection{Analysing and Synthesizing Data}

The statistical dependence between the elements described in Section 2.3 was determined using the Pearson Chi-square test. The Chi-square statistic is a non-parametric tool designed to analyse group differences when the dependent variable is measured at a nominal level [34], i.e., this test allows for identifying the association between two categorical variables [35]. The analysis was undertaken using a pairwise comparison between the categories described in Section 2.3. In SPSS v15.0 (SPSS Inc., Chicago, IL, USA) software.

\section{Results and Discussion}

\subsection{Overview}

A total of 183 papers were initially found, of which 150 papers were finally selected and reviewed: 27 in the period 2000-2004, 30 in the period 2005-2009, 22 in the period 2010-2014, and 71 in the period 2015-2020. Thirty three papers were discarded because they did not address exclusively freshwater ecosystems. Figure 1 shows the percentage of papers reviewed by category (Section 2.3).

Globally, the studies that dealt with Regulating FES represented the highest frequency (40\%) among selected publications, followed by the works that analysed FES in an integrated manner $(27.3 \%)$. The most usual class of MCDM methods found was mixed (26.7\%) and hierarchical $(22.0 \%)$, and the majority of the studies did not involve the preferences of stakeholder groups, $57.8 \%$ did not involve any type of participation, and $28.27 \%$ only included expert preferences. Near sixty-one percent of the publications came from the Paleartic biogeographic realm, particularly Europe, the Middle East, and China. Rivers $(46.7 \%)$ and wetlands $(24.0 \%)$ were the most studied waterbody types and problems related with management $(30.67 \%)$ and impact-vulnerability $(26.67 \%)$ assessment were the most frequently analysed.

\subsubsection{Ecosystem Services Class}

The majority of publications in the 2000-2020 period were in the class of regulating ES (Figure 1). Since 2015, there has been a significant decline in studies jointly addressing all ecosystem service types, giving way to studies that analyse them separately, with a particularly notable focus on the regulating services: in the latest period, these studies accounted for $47.89 \%$ of all the articles reviewed (Figure 2). Articles dealing with supporting functions have shown a marked increase in the last period, as have articles analysing the recreational functions of ecosystem services, albeit to a lesser extent. Interest in provisioning functions declined from 2010 onwards, but has levelled off since coming second behind regulating ecosystem services in the last period, with $14.08 \%$ per cent of the articles reviewed in that period. These results reflect a growing concern regarding aquatic ecosystem health, probably prompted by the deterioration of aquatic ecosystems around the world, mainly wetlands. 


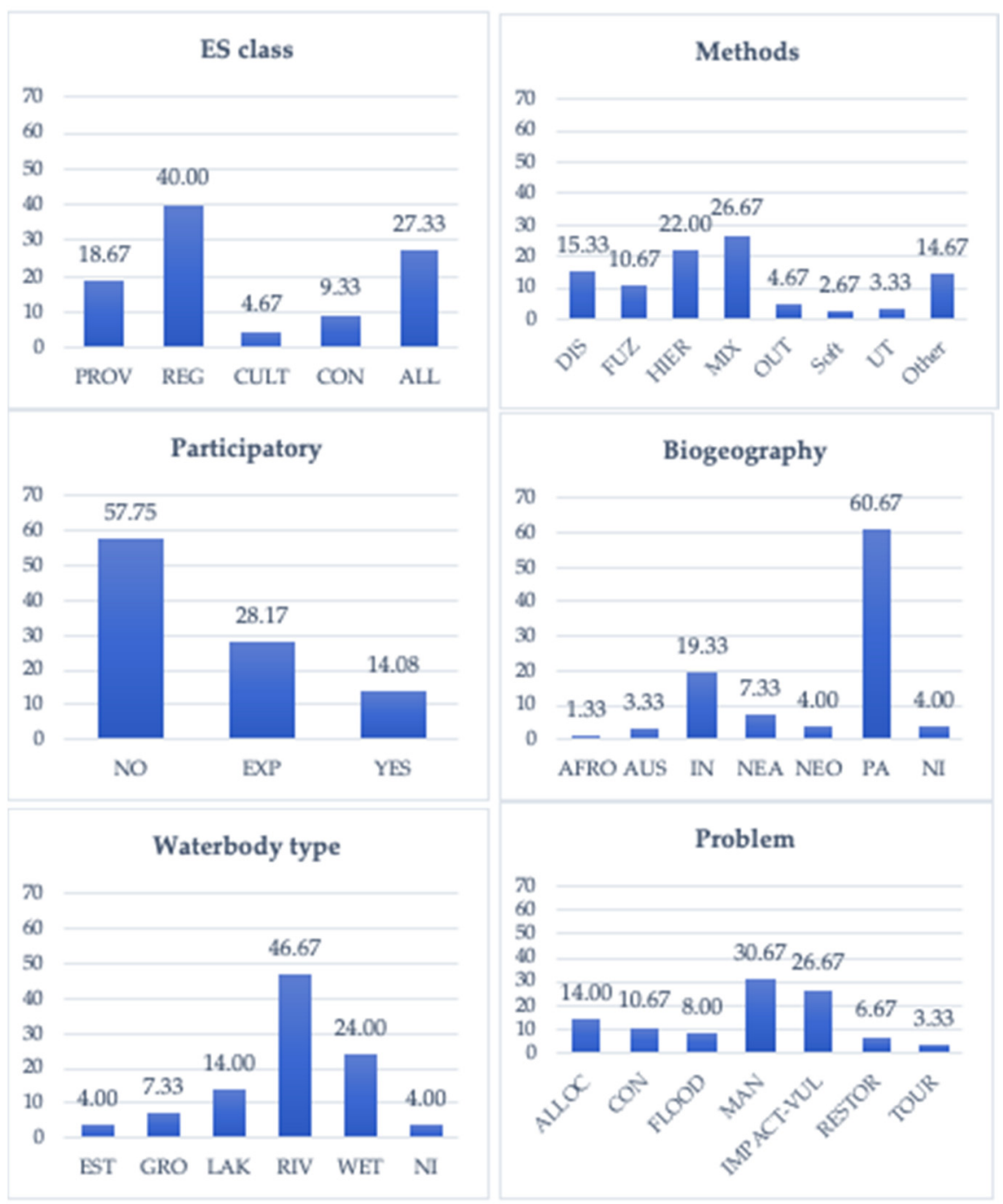

Figure 1. Percentage of papers by categories described in Section 2.3.

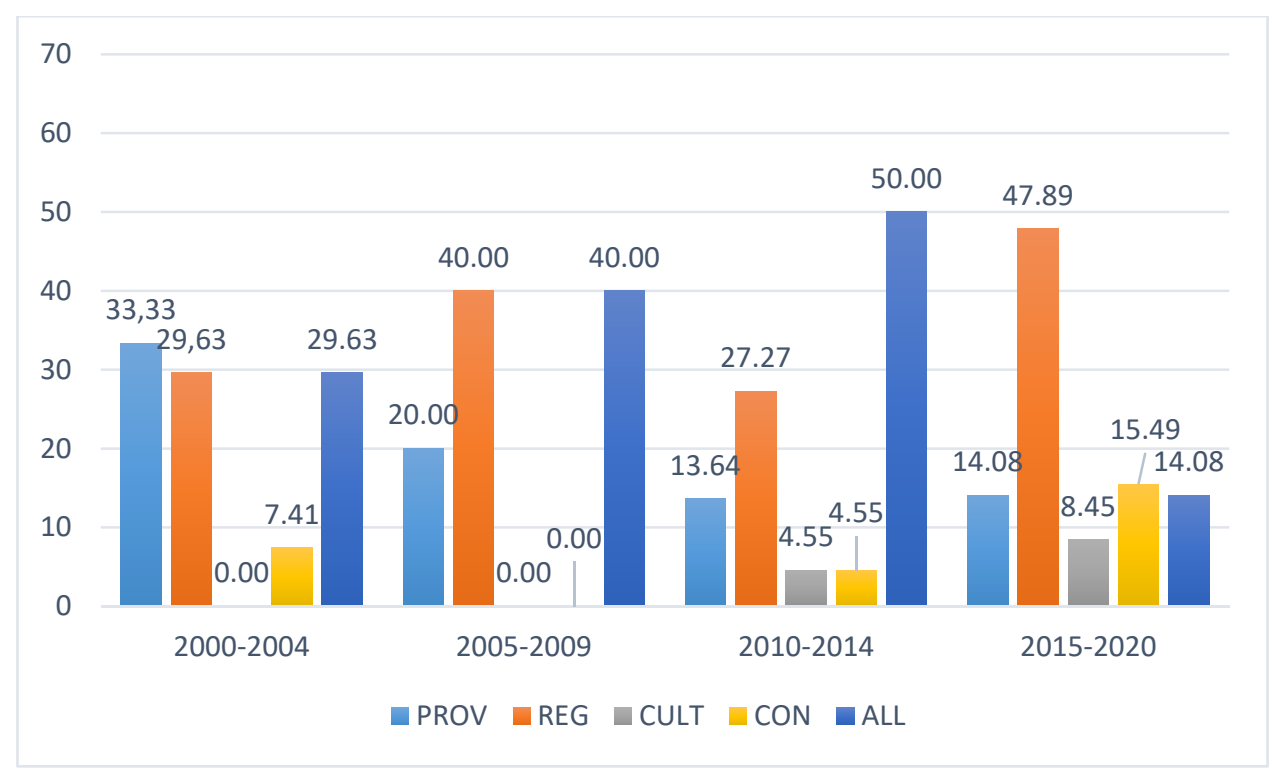

Figure 2. Percentage of papers by ecosystem service and period. For explanation of categories see Section 2.3. 


\subsubsection{MCDM Method}

The most usual methods to the analysis of FES are mixed and hierarchical methods (Figure 1). Particularly interesting is the evolution of mixed methods, which have increased along the time, achieving $36.6 \%$ of the reviewed papers in the last (2015-2020) period (Figure 3). Hierarchical methods have been more or less stable, after they increased from $2005-2009$ period $(16.7 \%)$ to figures around $25-27 \%$. Fuzzy, outranking, and utility methods have decreased over time. Utility methods, in fact, disappeared after 2010 (Figure 3). This could be because of the complexity of the collection of data to apply this type of methods, such as MAUT or MAVT. On the other hand, "Other methods" increased (Figure 3). This group includes new models and methods not included in the remaining classes. Particularly interesting are methods that are based on neural networks or random forest, which were applied in diverse manners to solve FES problems.

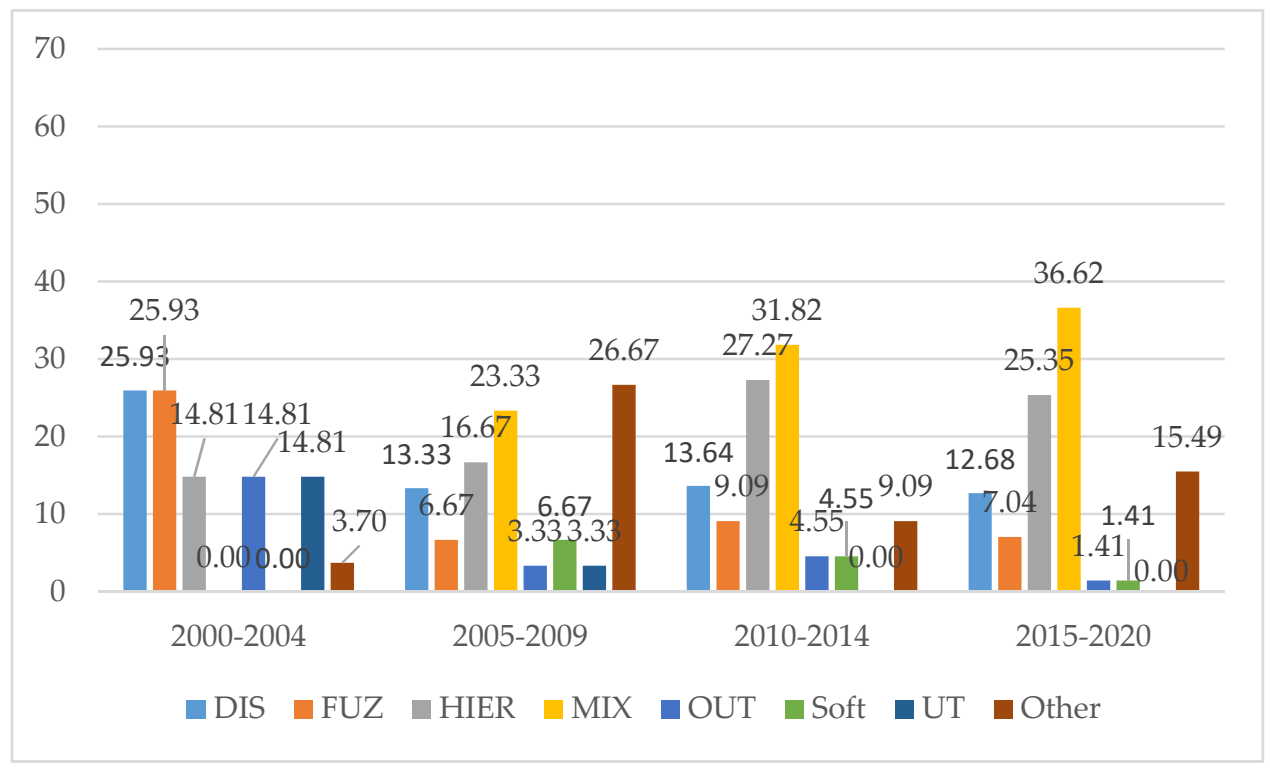

Figure 3. Percentage of papers by MCDM method and period. For explanation of categories see Section 2.3.

\subsubsection{Participation}

With regard to the evolution over time of participatory studies, the decrease in analyses involving stakeholder participation from the period 2005-2009 is particularly striking (Figure 4). It stands in contrast to the increase in studies that do not involve the participation of any type of stakeholder, or that relied on the participation of experts or water negotiators (Figure 4). This trend seems to be related to the decrease of studies that dealt with FES in an integrated manner since 2010. Taking into account that MCDM methods are particularly useful to the aggregation of different groups providing transparency and rigor to complex decision-making processes and the difficult to make strategic decisions by nations, regions, and local communities regarding water conflicts, this fact is unexpected. Section 3.2.5 discussed this more-in-depth. 


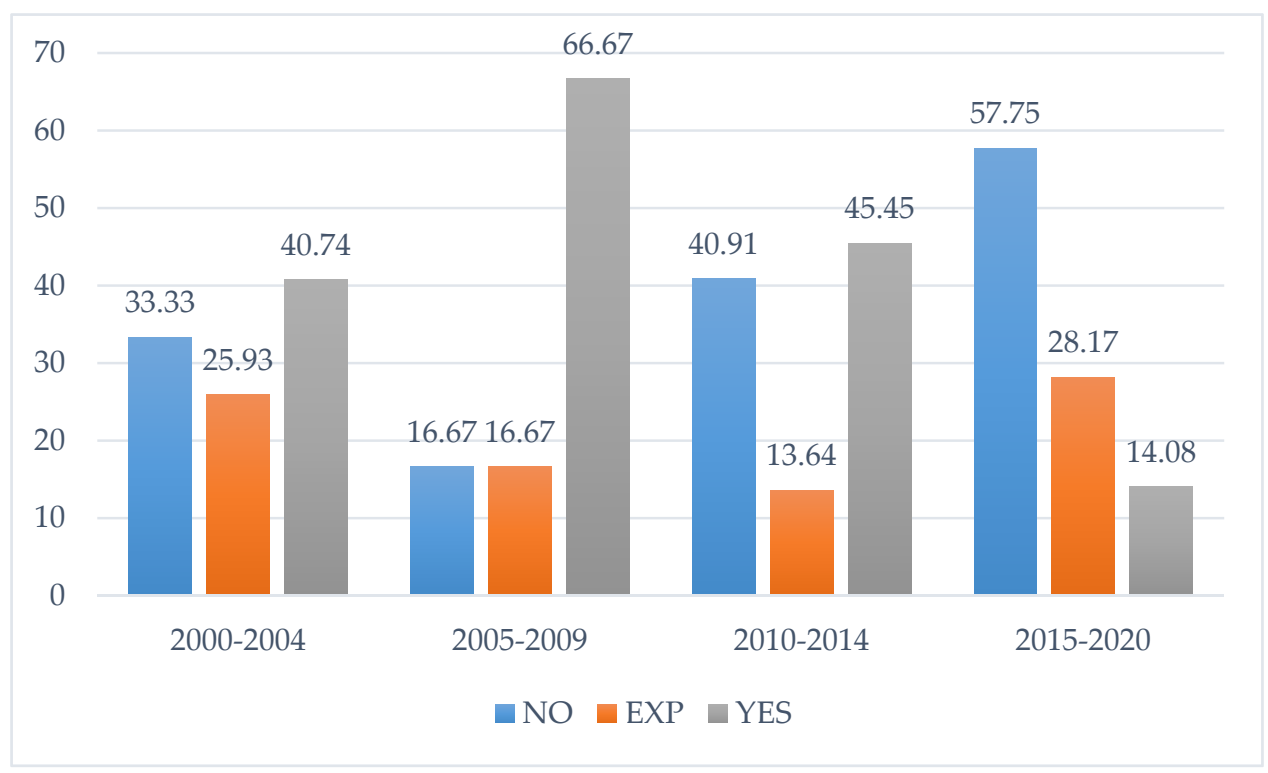

Figure 4. Percentage of papers by participatory approach and period. For explanation of categories see Section 2.3.

\subsubsection{Biogeographic Realms}

The Paleartic (PA) biogeographic realm was the one where the majority of FES studies were conducted, representing 53 to $64 \%$ of the reviewed papers (Figure 5). Indomalaya (INDO) was the second most important biogeographic realm, showing increasing importance over the period covered: $3.7 \%$ of the overall papers in $2000-2004$ to near $27 \%$ in 2015-2020 (Figure 5). No papers were found for the Neartic biogeographic realm. As it would be expected, countries with more scarcity of water are the ones that are most concerned about studying FES, as is the case of Iran, Iraq, and Afghanistan in the Paleartic region or India in the Indomalaya region.

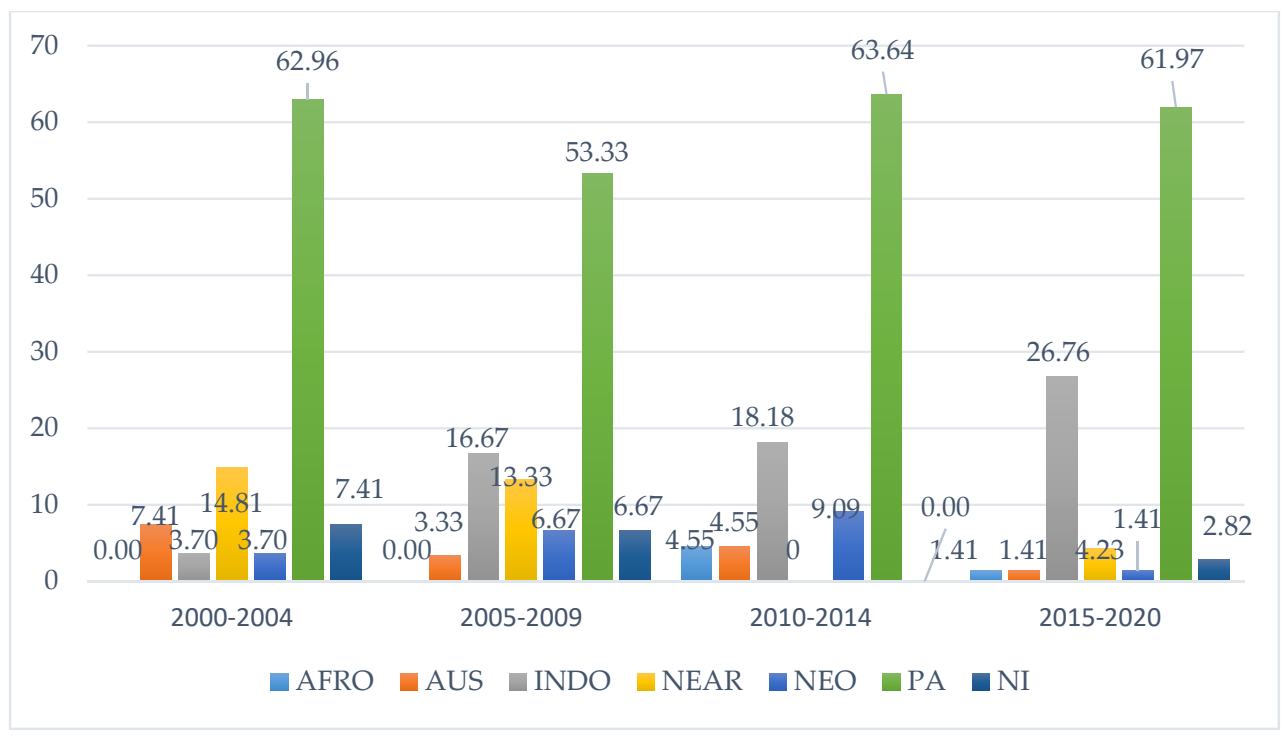

Figure 5. Percentage of papers by Biogeographic realm and period. For explanation of categories see Section 2.3.

Some works could not be included in a specific biogeographic realm because they were theoretical or modelling and simulation works, and were categorized as "Not identified" (NI). 


\subsubsection{Waterbody Type}

Globally, rivers have been the most analysed freshwater ecosystem (46.7\%) (Figure 1). However, since 2010, this waterbody type has decreased in frequency in favour of wetlands that have progressively increased ovel time representing $33.8 \%$ of the reviewed studies in 2015-2020 (Figure 6).

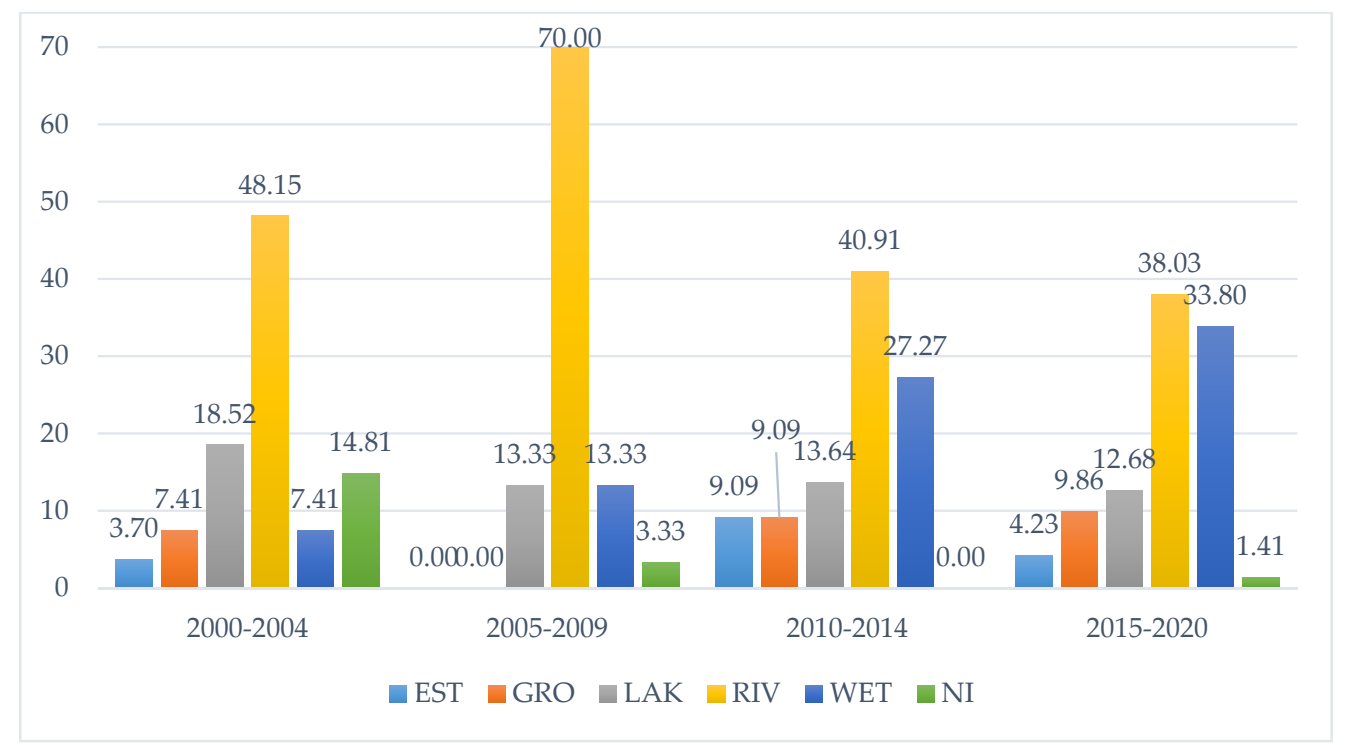

Figure 6. Percentage of papers by waterbody type and period. For explanation of categories see Section 2.3.

Groundwater studies increased in the last two periods, involving $9.9 \%$ of the papers that were reviewed between 2015 and 2020. Lakes have been slightly less studied, decreasing in frequency inform the first $(18.5 \%)$ to the last period $(12.7 \%)$. Estuaries have not followed a regular trend over the 20-year period considered (Figure 6).

Ninety-two percent of studies on wetlands sought to solve problems by analysing impact or vulnerability and conservation management and they were aimed at protecting the supporting and regulating FES.

According to the latest data, wetlands cover 12.1 million km2 globally. Between 1970 and $2015,35 \%$ of natural wetlands were lost (three times the rate of forest loss), while $81 \%$ of inland wetland species populations and $36 \%$ of coastal species declined [36]. Increasing wetland pollution, invasive species, and rapid urban development currently present a grave threat to wetlands. These data certainly justify the studies aimed at preserving the ecological functions of wetlands.

\subsubsection{Problems}

Up to the period 2015-2020, the most commonly studied problem was water management (MAN), with 44.4 to $46.7 \%$ of the publications in each of the three initial periods, as shown in Figure 7. However, in the last period, the proportion of publications focused on water management dropped to $14.1 \%$, accompanied by a growing interest in the assessment of the impact and vulnerability (IMPACT-VUL) of aquatic ecosystems $(39.4 \%)$ and in conservation aspects $(\mathrm{CON}), 16.9 \%$ of the publications in this period. 


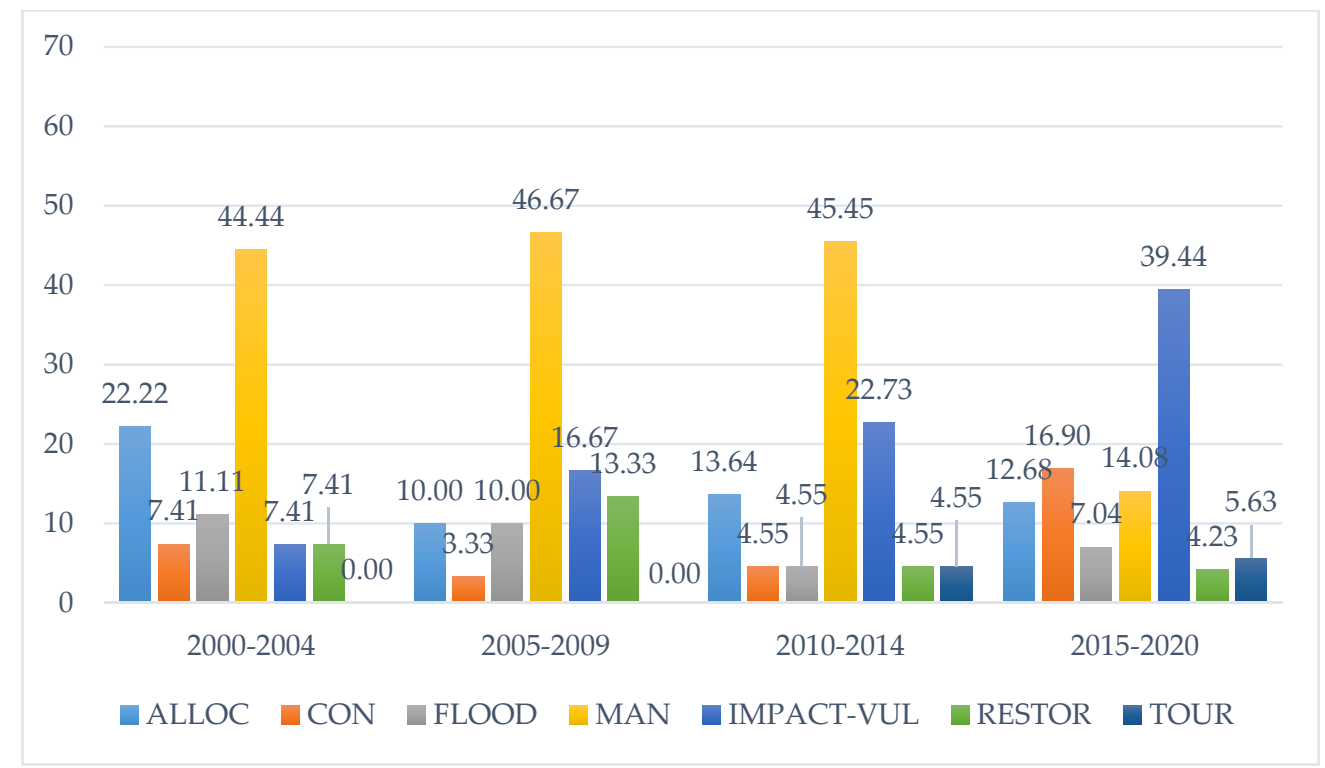

Figure 7. Percentage of papers by problem and period. For explanation of categories see Section 2.3.

Near $70 \%$ of all the participative studies dealt with management problems. This result could be expected since management problems are usually related with social an economic issues. Near $75 \%$ of the studies whose objective was related to conservation, $50 \%$ to restoration, and nearly $86 \%$ related to tourism, did not considered preferences of stakeholders. Although this could also be expected, this detachment of stakeholders in decision making is one of the most important problems in nature conservation, and it is a source of strong conflicts in rural areas, especially in protected areas. As an example, the restoration of a watershed involves many actions causing changes in the landscape and in different resources, often affecting a relevant number of stakeholders. Decisions regarding tourism planning also affect residents and other people with interests in specific sites. Failing to involve owners, managers, and residents in decision making in cases like these can create feelings of frustration within some stakeholders' groups, generating conflicts that sometimes result in environmental crimes, such as illegal fire-setting or wildlife poisoning [37].

\subsection{Relationships among Attributes}

The review identified a total of $28(18.7 \%)$ articles on provisioning, $60(40.0 \%)$ on regulating, $7(4.7 \%)$ on cultural, $14(9.3 \%)$ on supporting, and $41(27.33 \%)$ on simultaneously provisioning, regulating or cultural ecosystem services. Within each class of FES, we reviewed, in detail, the publications selected in this study adopting the classification described in Section 2.3. The Chi-square test indicated significant relationships between type of FES, biogeographic realm, method, problem, and participation $(p=0.00)$. These relationships are described and discussed in detail in Sections 3.2.1-3.2.5.

\subsubsection{Provisioning FES}

Although there has been a reduction in the number of articles analysing water as a provisioning ecosystem service since 2010 , over the total period, $75 \%$ of the articles have, to a greater or lesser extent, analysed water from this perspective (Table 1). Most of these articles have focused on the Palearctic realm, especially arid and semi-arid regions, such as Iran, Afghanistan, or India, and they have addressed problems of resource allocation and the identification of potential sources of provisioning services. In this regard, a degree of dependence between countries and methods has been identified $(p=0.051)$, with the analysis showing a tendency to use hierarchical methods in India.

Water resources management has mainly been studied using mixed and hierarchical methods $(46.43 \%)$ with the involvement of experts. AHP has been the most widely-used 
method to analyse water as a resource. To address related issues, Jaber and Mohsen [38], Chowdhuri et al. [39], Machiwal et al. [40], Machiwal et al. [41], Çelik [42], and Rana and Suruanarayana [43] used AHP; all but [38] combined it with GIS to do so. Swetha et al. [44] also used GIS with a hierarchical method, but in that case with ANP.

Two articles have been found that use outranking methods-Prato [45] and Hyde et al. [46] and two others that have use utility functions-Arriaza et al. [47] and Lopez-Baldovi et al. [48], with the latter two both focusing on Spain.

The mixed methods that are applied in this type of analysis generally combine stochastic methods, such as Bayesian networks with utility functions, outranking, or fuzzy methods, usually with GIS.

Of the 28 articles that were reviewed in this group, only four have involved stakeholder participation in some way, while eight have involved expert participation, and 16 articles have proposed models that do not incorporate any type of participation. In the latter case, they have performed simulations or worked with analyses of non-participatory scenarios.

Arriaza et al. [47] are the only authors who adopted a semi-participatory approach to address the allocation of water resources, when considering the interests of the different groups of stakeholders. They proposed a model based on utility functions to improve efficiency in the allocation of water resources and examined a case study in the Guadalquivir River Basin (Spain) involving water allocation to three groups of farmers. Although the model did not incorporate the interaction of these groups, they were asked about their degree of agreement with the results.

Mysiak et al. [49] and Rouzbahani et al. [50] also involved stakeholders to resolve management problems. A tool was proposed by Mysiak et al. [49] for the integration of hydrological models in a decision support system for water management, while considering the preferences of different stakeholders and applying it in five European countries. Rouzbahani et al. [50] analysed a number of different scenarios for aquifer restoration in Iran, using Bayesian networks, TOPSIS, SAW, and PROMETHEE II methods, accounting for the socio-cultural acceptance of stakeholders. Although the focus was on the restoration of these aquifers, the purpose was to ensure water supply to the affected regions.

Zarghami [51] and Estalaki et al. [52] also considered stakeholders in their studies of the impact of different management policies. Different water management alternatives were analysed by Zarghami [51] by means of a stochastic approach, using fuzzy quantifiers to incorporate the assessment of various stakeholders. Fuzzy social choice was used by Estalaki et al. [52] to incorporate stakeholder participation in the assessment of the impact of management policies on water quality in Iran.

Finally, a relationship was found between problem and participation $(p=0.015)$; studies that solve problems aimed at addressing resource allocation issues are the least likely to consider stakeholder preferences, as opposed to impact/vulnerability studies. 


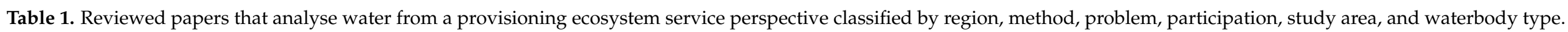

\begin{tabular}{|c|c|c|c|c|c|c|}
\hline Reference & Region & Method & Problem & Participation & Study area & Water Course Type \\
\hline Jaber and Mohsen, 2001 [38] & Jordania & HIER & ALLOC & $\mathrm{NO}$ & Ceyhanand Seyhan River & River \\
\hline Nayak and Panda, 2001 [53] & India & FUZ & ALLOC & EXP & Mahanadi Delta & River \\
\hline Arriaza et al., 2002 [47] & Spain & UT & ALLOC & YES & Guadalquivir Valley & River \\
\hline Mimi and Sawalhi, 2003 [22] & $\begin{array}{l}\text { Jordania, Israel, } \\
\text { Palestina }\end{array}$ & DIS & ALLOC & EXP & Jordan River & River \\
\hline Prato, 2003 [45] & USA & OUT & MAN & $\mathrm{NO}$ & Missouri River & River \\
\hline Hyde et al., 2004 [46] & Spain-Adelaide & OUT & ALLOC & EXP & $\begin{array}{c}\text { Flumen Monegros-Northern } \\
\text { Adelaide Plains }\end{array}$ & River \\
\hline Karnib, 2004 [54] & Theoretical & FUZ & MAN & $\mathrm{NO}$ & - & - \\
\hline McPhee and Yeh, 2004 [55] & USA & FUZ & MAN & $\mathrm{NO}$ & Upper San Pedro River Basin & River \\
\hline Srdjevic et al., 2004 [56] & Brazil & DIS & ALLOC & $\mathrm{NO}$ & Paraguaçu River basin & River \\
\hline Mysiak et al., 2005 [49] & Various & Other & MAN & YES & - & River \\
\hline López-Baldoví et al., 2006 [48] & Spain & UT & ALLOC & $\mathrm{NO}$ & Guadalquivir Valley & River \\
\hline Zarghaami, 2006 [57] & Irán & DIS & ALLOC & EXP & Polrud River basin & River \\
\hline Zarghami and Szidarovszky, 2009 [51] & Hungary & MIX & $\begin{array}{l}\text { IMPACT- } \\
\text { VUL }\end{array}$ & YES & Central Tisza River & River \\
\hline Gómez-Limón and Riesgo, 2009 [59] & Spain & MIX & MAN & EXP & Duero basin & River \\
\hline
\end{tabular}


Table 1. Cont.

\begin{tabular}{|c|c|c|c|c|c|c|}
\hline Reference & Region & Method & Problem & Participation & Study area & Water Course Type \\
\hline Chowdhury et al., 2010 [39] & India & HIER & ALLOC & EXP & $\begin{array}{l}\text { Subarnarekha and Kasai } \\
\text { Rivers }\end{array}$ & Groundwater \\
\hline Machiwal et al., 2011 [40] & Theoretical & HIER & ALLOC & $\mathrm{NO}$ & - & Lake \\
\hline Opricovic, 2011 [60] & Serby & MIX & MAN & $\mathrm{NO}$ & Mlava River & River \\
\hline Machiwal et al., 2015 [41] & India & HIER & ALLOC & $\mathrm{NO}$ & Ahar catchment & Groundwater \\
\hline Estalaki et al., 2016 [52] & Iran & FUZ & $\begin{array}{l}\text { IMPACT- } \\
\text { VUL }\end{array}$ & YES & Chitgar Lake & Lake \\
\hline Swetha et al., 2017 [44] & India & HIER & ALLOC & $\mathrm{NO}$ & Kuttiyadi River basin & Groundwater \\
\hline Zeng et al., 2017 [61] & China & Other & ALLOC & $\mathrm{NO}$ & Guanting reservoir basin & River \\
\hline Roozbahani et al., 2018 [50] & Iran & MIX & MAN & YES & Lake Urmia & Lake \\
\hline Arabameri et al., 2019 [62] & Iran & DIS & ALLOC & $\mathrm{NO}$ & Shahroud plane & Groundwater \\
\hline Bera and Bnik, 2019 [63] & India & Oher & ALLOC & $\mathrm{NO}$ & Kansachara watershed & River \\
\hline Çelik, 2019 [42] & Turkey & HIER & ALLOC & EXP & Tigris River & Groundwater \\
\hline Arabameri et al., 2020 [64] & Iran & MIX & ALLOC & $\mathrm{NO}$ & Bastam watershed & Groundwater \\
\hline
\end{tabular}




\subsubsection{Regulating FES}

The 60 articles dealing with water from a regulating ecosystem service perspective (Table 2) have primarily studied problems relating to flood control and the vulnerability, impact and restoration of lakes and wetlands, and on the capacity of wetlands to regulate biological cycles.

The most commonly used methods in this group are hierarchical (28.3\%) and mixed $(25 \%)$, but the review yields a substantial number of studies using other methods $(16.7 \%)$, distance-based methods (11.7\%), and fuzzy sets (10\%).

A total of $51.7 \%$ of the reviewed studies have addressed problems that are associated with impact or vulnerability, of which $41.9 \%$ involved expert participation and $54.8 \%$ did not include any type of participation. Only one article in this group took stakeholder preferences into account [65].

The only relationship of dependence found was between the problem to be solved and participation $(p=0.019)$. A mere $20 \%$ of the articles that were reviewed in this group incorporated stakeholder participation. For example, Janssen et al. [66] attempted to resolve management problems using the software package DEFINITE with GIS to assess wetland functions and the impact of three management alternatives: modern peat pasture, historical peat pasture, and dynamic mire.

Brouwer and Ek [67], Levy [68], Kenyon [69], Levy et al. [70], and Perrone et al. [71] focused on the study of flood control problems.

An integrated model of flood control policies was proposed by Ek [67] in the Netherlands, considering effects, such as land use change and floodplain restoration, using cost-benefit analysis and a multicriteria analysis in order to incorporate the participants' judgement in the model. Flood risk management was evaluated by Kenyon [69] in Scotland, using a participative approach. She used citizens' juries, deliberative monetary evaluation, and multi-criteria visual methods, considering criteria, such as looks, nature, cost, maintenance, safety, and flooding. Levy et al. [70] proposed a multi-criteria decision support tool to enhance communication among stakeholders and improve emergency management resource allocation in Tokai (Japan). A collaborative approach based on fuzzy methods was proposed by Perrone et al. [71] to manage flood risk in a river in Italy.

Rohde et al. [72], Randhir and Shriver [73], and Gross and Hagy [74] studied restoration issues. In an application to the Rhône-Thur river project, Rohde et al. [72] used GIS and MCDM for an integrated assessment of different river restoration strategies, jointly evaluating environmental criteria, such as natural flow and sufficient bed load material and socio-economic criteria associated with public attitude.

A deliberative attribute prioritization procedure using AHP was applied by Randhir and Shriver [73] to the case of subwatersheds for restoration in the Chicopee river in western Massachusetts, USA.

Restoration issues were also addressed by Gross and Hagy [74] using a participatory approach, in this case focusing on lakes and estuaries degraded by nutrient pollution. They analysed 16 case studies in different lakes and estuaries around the world to identify common attributes for nutrient management and variations thereof and explored the relationships between them using multicriteria analysis.

Daneshvar et al. [65] evaluated the impact of natural wetland implementation on total phosphorus reduction in the Saginaw River Watershed (Michigan) using the VIKOR method and SWAT model in order to provide a guide for policymakers. 


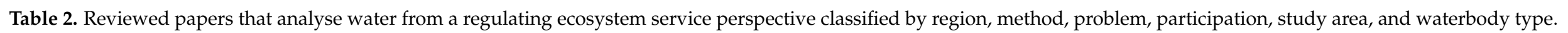

\begin{tabular}{|c|c|c|c|c|c|c|}
\hline Reference & Region & Method & Problem & Participation & Study Area & Water Course Type \\
\hline Arondel and Girardin, 2000 [75] & France & FUZ & $\begin{array}{l}\text { IMPACT- } \\
\text { VUL }\end{array}$ & EXP & Rhine Plain & Groundwater \\
\hline Chuntian and Chau, 2002 [76] & China & FUZ & FLOOD & $\mathrm{NO}$ & Fengman Reservoir & River \\
\hline Wang et al., 2003 [77] & China & HIER & $\begin{array}{l}\text { IMPACT- } \\
\text { VUL }\end{array}$ & $\mathrm{NO}$ & Jianghan Plain & Wetland \\
\hline Bana e Costa et al., 2004 [78] & Portugal & UT & FLOOD & EXP & $\begin{array}{l}\text { Livramento creek in the } \\
\text { peninsula of Setúbal }\end{array}$ & River \\
\hline Brouwer and Ek, 2004 [67] & Netherlands & Other & FLOOD & YES & River Rhine and Meuse Delta & River-Wetland \\
\hline Herath, 2004 [79] & Victoria & HIER & MAN & YES & Wonga Wetlands & Wetland \\
\hline Olenick et al., 2004 [80] & USA & DIS & MAN & $\mathrm{NO}$ & $\begin{array}{c}\text { Edwards Aquifer and Twin } \\
\text { Buttes watersheds }\end{array}$ & Other \\
\hline Tzionas et al., 2004 [81] & Greece & FUZ & RESTOR & EXP & Lake Koronia & Lake \\
\hline Almasri and Kaluarachchi, 2005 [82] & Whashington & NEU & $\begin{array}{l}\text { IMPACT- } \\
\text { VUL }\end{array}$ & $\mathrm{NO}$ & Sumas-Blaine aquifer & River \\
\hline Janssen et al., $2005[66]$ & Germany & Other & MAN & YES & Noord-Hollands Midden & Wetland \\
\hline Lee and Chang, 2005 [83] & Taiwan & FUZ & $\begin{array}{l}\text { IMPACT- } \\
\text { VUL }\end{array}$ & $\mathrm{NO}$ & Tou-Chen River basin & River \\
\hline Levy, 2005 [68] & China & HIER & FLOOD & YES & Tokai flood & River \\
\hline Elshorbagy, 2006 [84] & Canadá & OUT & RESTOR & $\mathrm{NO}$ & $\begin{array}{c}\text { Fort McMurray (reconstructed } \\
\text { watershed) }\end{array}$ & River \\
\hline Liu et al., 2006 [85] & New South Wales & DIS & RESTOR & EXP & Clarence River & Wetland \\
\hline Rohde et al., 2006 [72] & Switzerland & Other & RESTOR & YES & Rhône-Thur Rivers & River \\
\hline Kenyon, 2007 [69] & Scotland & SOFT & FLOOD & YES & Scotland (general) & River \\
\hline Levy et al., 2007 [70] & Japan & HIER & FLOOD & YES & $\begin{array}{l}\text { Shinkawa and the Shonai } \\
\text { rivers (Tokai floods) }\end{array}$ & River \\
\hline
\end{tabular}


Table 2. Cont.

\begin{tabular}{|c|c|c|c|c|c|c|}
\hline Reference & Region & Method & Problem & Participation & Study Area & Water Course Type \\
\hline Li, $2007[86]$ & China & HIER & $\mathrm{CON}$ & EXP & Chaohu Lake & Lake \\
\hline Qin et al., 2008 [87] & Canadá & MIX & IMPACT-VUL & EXP & Georgia basin & River \\
\hline Olu-Owolabi et al., 2012 [88] & Nigeria & FUZ & IMPACT-VUL & $\mathrm{NO}$ & Ondo coast & Estuary \\
\hline Sun et al., 2012 [89] & China & MIX & IMPACT-VUL & $\mathrm{NO}$ & Dayang Estuary & Wetland-Estuary \\
\hline Wu et al., 2012 [90] & China & MIX & ALLOC & YES & Qixinghe & Wetland \\
\hline Sener and Davraz, 2013 [91] & Turkey & HIER & IMPACT-VUL & $\mathrm{NO}$ & Egirdir Lake basin & Groundwater \\
\hline Lee et al., 2014 [92] & Korea & MIX & FLOOD & $\mathrm{NO}$ & Han River & River \\
\hline Malekmohammadi and Blouchi, 2014 [93] & Iran & HIER & IMPACT-VUL & EXP & Shadegan Wetland & Wetland \\
\hline Chatterjee et al., 2015 [94] & India & MIX & IMPACT-VUL & $\mathrm{NO}$ & Keoladeo National Park & Wetland \\
\hline McVittie et al., 2015 [95] & Theoretical & Other & IMPACT-VUL & NO & Theoretical & River \\
\hline Meraj et al., 2015 [96] & India & Other & FLOOD & $\mathrm{NO}$ & $\begin{array}{l}\text { Lidder and Rembiara watersheds } \\
\text { of the Jhelum basin }\end{array}$ & River \\
\hline Walker et al., 2015 [98] & Serbia & Other & IMPACT-VUL & $\mathrm{NO}$ & Danube River & River \\
\hline Abd-El Monsef et al., 2017 [99] & Egypt & HIER & $\mathrm{CON}$ & $\mathrm{NO}$ & Sharm El-Bahari & Wetland \\
\hline Daneshvar et al., 2017 [65] & USA & DIS & IMPACT-VUL & YES & Saginaw River watershed & Wetland \\
\hline Duodu et al., 2017 [100] & Queensland & OUT & IMPACT-VUL & $\mathrm{NO}$ & Brisbane River & River \\
\hline Gross and Hagy, 2017 [74] & Various & SOFT & RESTOR & YES & Various & Lake-Estuary \\
\hline Man et al., 2017 [101] & China & HIER & $\mathrm{CON}$ & $\mathrm{NO}$ & Sanjiang plain & Wetland \\
\hline $\begin{array}{l}\text { Malekmohammadi and Jahanishakib, } \\
2017 \text { [102] }\end{array}$ & Iran & HIER & IMPACT-VUL & EXP & Choghakhor Wetland & Wetland \\
\hline Rather et al., 2017 [103] & India & Other & IMPACT-VUL & $\mathrm{NO}$ & Jhelum Basin & River \\
\hline Golbarg et al., 2018 [104] & Iran & HIER & IMPACT-VUL & EXP & Shadegan International Wetland & Wetland \\
\hline Maleki et al., 2018 [105] & Afghanistan-Iran & HIER & RESTOR & $\mathrm{NO}$ & Hamun Wetlands & Wetland \\
\hline
\end{tabular}


Table 2. Cont.

\begin{tabular}{|c|c|c|c|c|c|c|}
\hline Reference & Region & Method & Problem & Participation & Study Area & Water Course Type \\
\hline Rahdari et al., 2018 [106] & Iran & MIX & $\mathrm{CON}$ & EXP & $\begin{array}{l}\text { Gavkhooni Wetland-Plasjan } \\
\text { sub-bsin }\end{array}$ & River-Wetland \\
\hline Arabameri et al., 2019 [107] & Iran & DIS & IMPACT-VUL & EXP & Semnan watershed & River \\
\hline Bid and Siddique, 2019 [108] & India & DIS & FLOOD & EXP & Damodar River-Panchet dam & River \\
\hline de Souza et al., 2019 [109] & Brazil & MIX & IMPACT-VUL & EXP & Doce River basin & River \\
\hline Ghosh and Das, 2019 [110] & India & MIX & IMPACT-VUL & $\mathrm{NO}$ & East Kolkata Wetland (Ramsar) & Wetland \\
\hline Roy and Majumder, 2019 [112] & India & Other & IMPACT-VUL & $\mathrm{NO}$ & Loktak Lake & Lake \\
\hline Xu et al., 2019 [113] & China & HIER & IMPACT-VUL & $\mathrm{NO}$ & Xiangjian River basin & River \\
\hline Akay and Koçyigit, 2020 [114] & Turkey & MIX & FLOOD & $\mathrm{NO}$ & Akçay basin & River \\
\hline Alamanos and Papaioannou, 2020 [115] & Canadá & HIER & IMPACT-VUL & EXP & Lake Erie watershed & Wetland \\
\hline Arabameri et al., 2020 [116] & Iran & HIER & IMPACT-VUL & EXP & Kalvari basin & River \\
\hline Bhattacharya et al., 2020 [117] & India & DIS & IMPACT-VUL & $\mathrm{NO}$ & Kangsabati basin & River \\
\hline Ghosh and Das, 2020 [119] & India & NEU & IMPACT-VUL & EXP & East Kolkata Wetland (Ramsar) & Wetland \\
\hline Perrone et al., 2020 [71] & Italy & FUZ & FLOOD & YES & Bradano River & River \\
\hline Popovic et al., 2020 [120] & Serbia & MIX & RESTOR & $\mathrm{NO}$ & Lake Vrutci & Lake \\
\hline Sarkar and Majumder, 2020 [121] & India & MIX & IMPACT-VUL & EXP & Tripura River & River \\
\hline Souissi et al., 2020 [122] & Tunisia & HIER & FLOOD & EXP & Gabes region & River \\
\hline Sun et al., 2020 [123] & China & MIX & FLOOD & $\mathrm{NO}$ & Yangtze River delta & River \\
\hline Yang and Wang, 2020 [124] & China & DIS & IMPACT-VUL & EXP & Taihu basin & Lake-River \\
\hline
\end{tabular}




\subsubsection{Cultural FES}

A total of seven articles have been identified that deal with recreational services of freshwater ecosystems, six of them in the last period analysed (Table 3). Zhang et al. [125] used TOPSIS to evaluate competitive tourist destinations in the Yangtze River Delta (China) and Tang et al. [126] used fuzzy techniques to evaluate the coordinative green development of tourist experience and commercialization of tourism when considering the perspectives of tourists in the Ancient City of Pingyao and West Lake Cultural Landscape of Hangzhou (China). Aiping et al. [127] used AHP and GIS to identify and map ecotourism areas in one area of the Yellow River (China). Biglarfadafan et al. [128] and Tang et al. [126] both assessed impact/vulnerability, while the rest identified suitable places for tourism. The suitability of areas for birdwatching was identified by Biglarfadafan et al. [128] in wetlands, as well as the impact of ecotourism, and Tang et al. [126] studied the green development of tourism in a protected area. The studies were carried out in Iran and China, and none of them accounted for stakeholder preferences.

Table 3. Reviewed papers that analyse water as a cultural ecosystem service classified by region, method, problem, participation, study area, and waterbody type.

\begin{tabular}{|c|c|c|c|c|c|c|}
\hline Reference & Region & Method & Problem & Participation & Study Area & Water Course Type \\
\hline Zhang et al., 2011 [125] & China & DIS & TOUR & $\mathrm{NO}$ & Yangtze River Delta & River \\
\hline Aiping et al., 2015 [127] & China & HIER & TOUR & $\mathrm{NO}$ & Yellow River & Wetland \\
\hline Erfani et al., 2015 [129] & Iran & MIX & TOUR & NO & Hamoon Lake & Lake \\
\hline Biglarfadafan et al., 2016 [128] & Irán & MIX & IMPACT-VUL & NO & Bazangan Lake & Wetland \\
\hline Balist et al., 2019 [130] & Iran & MIX & TOUR & $\mathrm{NO}$ & Zarivar Lake & Lake \\
\hline Maghsoudi et al., 2019 [131] & Iran & MIX & TOUR & NO & Shur River (Lut desert) & River \\
\hline Tang et al., 2019 [126] & China & FUZ & IMPACT-VUL & NO & West Lake of Hangzhou & Wetland \\
\hline
\end{tabular}

\subsubsection{Supporting FES}

The 14 studies included in this group have a strict focus on site conservation, especially biodiversity conservation (Table 4). Only Qureshi and Harrison [132], Eliasson et al. [133], and Choulak et al. [134] incorporated stakeholder participation in resolving issues associated with supporting ES. The first of these studies evaluated different alternatives for riparian revegetation in a small sub-catchment in the Johnstone River catchment (North Queensland) while using hierarchical methods and a collaborative approach.

Eliasson et al. [133] evaluated the impact of the construction of a new road on an important glaciofluvial esker aquifer in Sweden. Scenario analysis and a multi-criteria decision model were used to examine the preferences of the main stakeholders in the affected municipalities, in order to assess four different alternatives accounting for conflicts with aquatic, agricultural, natural and cultural resources. A meta-decision analysis carried out by [134] in an application to wetland prioritization in the Bourgogne region (France), seeking to encourage and finance wetland conservation plans considering their contribution to biodiversity. Chen et al. [135] relied on expert participation in their study that aimed at improving wetland environmental protection plans, using DEMATEL and VIKOR techniques and a modified ANP. In this case, experts were consulted to identify four dimensions and 11 criteria to determine the best management alternative aimed at achieving the objective of wetland environmental protection.

Saha [136] and Talukdar et al. [137] focused on assessing the vulnerability of two Indian wetlands of the Atreyee River and Tangan River, respectively. The former used fuzzy logic, while the latter used random forest and neural networks to explore the habitat quality and Trophic State Index. Buruso [138] studied the suitability of Lake Tana as habitat for the African hippo, while Wu et al. [139] analysed the ecological value of 60 national parks (wetlands) in China. Jafari [140] also focused on analysing the ecological value of sites in Kavir National Park (Iran). 


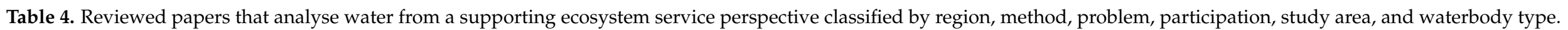

\begin{tabular}{|c|c|c|c|c|c|c|}
\hline Reference & Region & Method & Problem & Participation & Study Area & Water Course Type \\
\hline Qureshi and Harrison, 2001 [132] & Queensland & HIER & $\mathrm{CON}$ & YES & Johnstone River catchment & River \\
\hline Eliasson et al., 2003 [133] & Sweden & DIS & $\mathrm{CON}$ & YES & Aquifer Nybroåsen (Kalmar) & Groundwater \\
\hline Dong et al., 2013 [141] & China & HIER & $\mathrm{CON}$ & $\mathrm{NO}$ & West Songnen Plain & Wetland \\
\hline Kozlov et al., 2016 [142] & Rusia & Other & $\mathrm{CON}$ & $\mathrm{NO}$ & Volga-Akhtuba Wetlands & Wetland \\
\hline Qiu et al., 2016 [143] & USA & MIX & $\mathrm{CON}$ & $\mathrm{NO}$ & Raritan River basin & River \\
\hline Buruso, 2018 [138] & Ethiopia & Other & $\mathrm{CON}$ & $\mathrm{NO}$ & Lake Tana Biosphere Reserve & Lake \\
\hline Wu et al., 2017 [139] & China & HIER & $\mathrm{CON}$ & $\mathrm{NO}$ & 60 National Wetlands Parks & Wetland \\
\hline Qi et al., 2018 [145] & China & MIX & $\mathrm{CON}$ & $\mathrm{NO}$ & Lake Poyang & Lake \\
\hline Chen et al., 2019 [135] & Taiwan & MIX & MAN & EXP & Guan-Du Wetland & Wetland \\
\hline Choulak et al., 2019 [134] & France & MIX & $\mathrm{CON}$ & YES & Bourgogne comte & Wetland \\
\hline Saha and Pal, 2019 [136] & India & FUZ & $\begin{array}{l}\text { IMPACT- } \\
\text { VUL }\end{array}$ & $\mathrm{NO}$ & Atreyee River & Wetland-River \\
\hline Jafari et al., 2019 [140] & Iran & MIX & $\mathrm{CON}$ & $\mathrm{NO}$ & Kavir National Park & River \\
\hline Talukdar et al., 2020 [137] & India & NEU & $\begin{array}{l}\text { IMPACT- } \\
\text { VUL }\end{array}$ & $\mathrm{NO}$ & Tangan River & Wetland-River \\
\hline
\end{tabular}




\subsubsection{Integrated FES and Participation}

The strong decrease in analyses involving stakeholder participation from the period 2005-2009, as shown in the results, can be primarily explained by the growing concern about conservation, in the strict sense, and provisioning issues, which have not traditionally incorporated stakeholder participation in decision-making processes. The review identified another group of studies that approach water as an integrative element, analysing problems that are associated with its provisioning, regulating, cultural, and sometimes supporting functions, and which consider the interests of different stakeholder groups. There was a very substantial increase in the publications of this type of study in the period 2000-2005 and, to a lesser extent, in the second period 2006-2010, before decreasing significantly from 2011 onwards and contributing to the gradual decline in participatory studies of FES from 2011 (Figure 4).

Thirty-one studies (75.6\%) that take an integrated approach to analysing FES incorporated stakeholder participation. These studies were mainly conducted in European countries and address issues of sustainable management (Table 5). A high degree of dependence was identified between participation and the problem to be solved $(p=0.00)$ : the articles dealing with solving management problems were the most participatory.

In this group, only two papers dealt with problems of impact/vulnerability and restoration: Gregory and Wellman [146] and Azarnivand et al. [147]. A participative tool was proposed by Gregory and Wellman [146] to restore the functioning of the Tillamook Bay estuary with the values assessed by community residents. Azarnivand et al. [147] evaluated different alternatives for the restoration of Lake Urmia in Iran. To that end, they used an extended fuzzy analytical hierarchy process and a SWOT-TOWS matrix, while considering the preferences of stakeholders, managers, and experts.

Among the studies that jointly examined provisioning and regulating services, those involving stakeholder participation were Derak et al. [148], Weng et al. [149], and Dowlatabadi et al. [150]. Land use alternatives were evaluated by Derak et al. [148] evaluated in Beni Boufrah Valley, a semi-arid area of Morocco, incorporating 67 stakeholders' preferences regarding water supply, soil fertility, protection against erosion, and food provision. To do so, they used an AHP model. Multi-objective programming was used by Weng et al. [149] and proposed a decision support system for water resources management and planning in the Haihe River Basin (China), in which stakeholders could include their preferences in the assessment of different management scenarios. This is the only study carried out in China that incorporates stakeholder preferences into the model. DEMATEL, AHP, and game theory were used by Dowlabati et al. [150] to resolve conflicts surrounding a transboundary wetland, Hawizeh Wetland/Hoor-Al-Azim, involving Iran, Iraq, Turkey, and Syria. By applying the model, the authors were able to identify three strong equilibrium points among 15 feasible alternatives: establishing a regional agreement among Iran, Iraq, and Turkey to reduce the effects of conflicts on the wetland; an Iran-Iraq coalition to motivate Turkey to reduce water withdrawal from the Tigris River; and, exchanging water release for the commodity market in Iran and Iraq for Turkey.

Finally, two papers were identified that jointly analysed regulating and cultural functions. Väntänen and Marttunen [151] proposed several ways to include stakeholder participation in order to assess the impact of different regulation strategies on recreational use and aquatic ecosystems in a Finnish lake. Wang et al. [152] addressed tourism development in a wetland in China, considering its effect on the biochemical conditions of the water. To do so, they used fuzzy neuronal networks, but did not rely on the participation of stakeholders or experts. 
Environmental policies are implemented in complex socio-economic contexts, involving a large number of different stakeholder groups with diverse and often conflicting interests. Conflicts are exacerbated in a context of scarce resources, and often protected resources, as is the case with water. Nevertheless, although there are many links between water and conflicts, and many opposing interests have a bearing on its management, most disputes are resolved peacefully through negotiation processes; accordingly, since the early 2000s, different formulas for cooperation in water management have been promoted [153]. Generally speaking, economic cooperation between countries can be used as a negotiating tool for solving water problems [150].

Two key elements should be taken into account when it comes to managing waterrelated conflicts: the legislative framework and operational framework. Regarding the former, there is a need for a legal and regulatory framework to support the management of large watercourses. Indeed, in international river basins, water management institutions do not tend to manage conflicts if there is no treaty stating the rights and responsibilities of each nation, or any implicit agreement [153]. In terms of the operational framework, MCDM methods can be a very useful tool for identifying conflicts and efficiently managing them [154]. In addition to the scientific soundness of the models, participation plays a relevant role in a number of ways: on the one hand, expert recommendations are needed to improve their operability and support their legitimacy [134] and, on the other hand, incorporating participation in the early stages of the decision-making processes helps to minimise conflicts and facilitates their management in the development of public policies [155]. Alamanos et al. [156] provide an integrated decision support tool for evaluating water resource management strategies in a lake in Greece. They combined four MCDM techniques to assess seven alternative policies and involved experts and stakeholders to weight the analysed criteria and then compared the results. This illustrated the differences in the perception of the problems, and guided an integrated solution expressed by experts in the field of water management and by the responsible authorities. Moreover, this study compared several MCDM techniques, which is very useful for defining a complete framework of alternative possibilities when divergences between participants are strong. Papaioannou et al. Several multiple-criteria analysis methods were compared by [157] for potential flood prone areas mapping in the Xerias River watershed (Greece).

Although this is acknowledged by the scientific community and accepted by the general public, the present review has shown that, in recent years, there has been a trend towards the proliferation of non-participatory studies regarding MCDM methods aimed at solving problems of a strictly ecological nature without accounting for social preferences. 
Table 5. Reviewed papers that analyse water as an integrated ecosystem service.

\begin{tabular}{|c|c|c|c|c|c|c|c|}
\hline Reference & Region & Method & Problem & Ecosystem Service & Participation & Study Area & Water Course Type \\
\hline De Marchi et al., 2000 [158] & Sicilia & FUZ & MAN & PROV-REG-CULT & YES & Dam and lake in Ancipa & Lake \\
\hline Srinivasa et al., 2000 [159] & Spain & OUT & MAN & PROV-REG-CULT & NO & $\begin{array}{c}\text { Flumen Monegros irrigation } \\
\text { area (Hoya de Huesca and } \\
\text { Monegros) }\end{array}$ & River \\
\hline Gregory and Wellman, 2001 [146] & USA & UT & RESTOR & PROV-REG-CULT & YES & Tillamook Bay & Estuary \\
\hline Hamalainen et al., 2001 [160] & Finland & DIS & MAN & PROV-REG-CULT & YES & Lake Päijänne-River Kymikoki & Lake \\
\hline Pavlikakis and Tsihrintzis, 2003 [161] & Greece & DIS & MAN & PROV-REG-CULT & YES & $\begin{array}{l}\text { National Park of river Nestos } \\
\text { delta and Lakes Vistonida and } \\
\text { Ismarida }\end{array}$ & Lake \\
\hline Cai et al., 2004 [21] & China & DIS & MAN & PROV-REG-CULT & YES & Theoretical & NI \\
\hline Mustajoki et al., 2004 [162] & Finland & UT & MAN & PROV-REG-CULT & YES & Lake Päijänne & Lake \\
\hline Raju and Duckstein, 2004 [163] & Spain & OUT & MAN & PROV-REG-CULT & EXP & $\begin{array}{c}\text { Flumen Monegros irrigation } \\
\text { area }\end{array}$ & River \\
\hline Vantanen and Marttunen, 2005 [151] & Finland & SOFT & IMPACT-VUL & REG-CULT & YES & Lake Kemijärvi & Lake \\
\hline Wattage and Mardle, 2005 [164] & India & HIER & MAN & PROV-REG-CULT & YES & $\begin{array}{l}\text { Muthurajawela Marsh and } \\
\text { Negombo Lagoon }\end{array}$ & Wetland \\
\hline Messner et al., 2006 [165] & Germany & Other & MAN & PROV-REG-CULT & YES & Spree river basin & River \\
\hline Wang et al., 2006 [166] & China & FUZ & MAN & PROV-REG-CULT & YES & Lake Quionghai & Lake \\
\hline Marchamalo and Romero, 2007 [168] & Costa Rica & DIS & MAN & PROV-REG-CULT & YES & Birrís River & River \\
\hline Srdjevic, 2007 [169] & Brazil & MIX & MAN & PROV-REG-CULT & YES & San Francisco river basin & River \\
\hline Hajkowicz and Higgins, 2008 [170] & NI & Other & MAN & PROV-REG-CULT & YES & Various & NI \\
\hline Marttunen and Hamalainen, 2008 [14] & Finland & Other & MAN & PROV-REG-CULT & YES & Lake Päijänne-RIV Kymikoki & Lake \\
\hline Van Cauwenbergh et al., 2008 [171] & Spain & MIX & MAN & PROV-REG-CULT & YES & Andarax catchment & River \\
\hline Chung and Lee, 2009 [172] & Korea & MIX & MAN & PROV-REG-CULT & YES & $\begin{array}{l}\text { Anyangcheon watershed (Han } \\
\text { river) }\end{array}$ & River \\
\hline Ryu et al., 2009 [173] & Korea & DIS & MAN & PROV-REG-CULT & YES & Geum river basin & River \\
\hline Calizaya et al., 2010 [174] & Bolivia & HIER & MAN & PROV-REG-CULT & YES & Lake Poopo Basin (Ramsar) & Lake \\
\hline
\end{tabular}


Table 5. Cont.

\begin{tabular}{|c|c|c|c|c|c|c|c|}
\hline Reference & Region & Method & Problem & Ecosystem Service & Participation & Study Area & Water Course Type \\
\hline Chen et al., 2010 [175] & Taiwan & MIX & MAN & PROV-REG-CULT & YES & Pei-Keng watershed & River \\
\hline Silva et al., 2010 [176] & Brazil & OUT & MAN & PROV-REG-CULT & YES & Jabuatao River watershed & River \\
\hline Yilmaz and Harmancioglu, 2010 [177] & Turkey & DIS & MAN & PROV-REG-CULT & YES & Gediz River basin & River \\
\hline Weng et al., 2010 [149] & China & Other & MAN & PROV-REG & YES & Haihe river basin & River \\
\hline Chen et al., 2011 [178] & China & FUZ & MAN & PROV-REG-CULT & EXP & $\begin{array}{l}\text { Pei-Keng brook of catchments } \\
\text { area }\end{array}$ & River \\
\hline Lennox et al., 2011 [179] & New Zealand & SOFT & MAN & PROV-REG-CULT & YES & Canterbury region & River \\
\hline Wang et al., 2012 [152] & China & NEU & IMPACT-VUL & REG-CULT & NO & Others-Theoretical & Wetland \\
\hline Azarnivand et al., 2014 [147] & Iran & MIX & RESTOR & PROV-REG-CULT & YES & Lake Urmia & Lake \\
\hline Aznar et al., 2014 [180] & Spain & MIX & MAN & PROV-REG-CULT & YES & Pego-Oliva Wetland & Wetland \\
\hline Pinto et al., 2014 [181] & Portugal & DIS & MAN & PROV-REG-CULT & YES & Mondego Estuary & Estuary \\
\hline Aher et al., 2017 [182] & India & HIER & ALLOC & PROV-REG & NO & Dhalai River & River \\
\hline Derak et al., 2017 [148] & Morocco & HIER & MAN & PROV-REG & YES & Beni Boufrah Valley & River \\
\hline Sheikhipour et al., 2018 [183] & Iran & MIX & MAN & PROV-REG-CULT & NO & Shahrekord aquifer & Groundwater \\
\hline DasGupta et al., 2019 [184] & India & DIS & MAN & PROV-REG-CULT & YES & Indian Sundarban Delta & Estuary \\
\hline Everard et al., 2019 [185] & India & other & MAN & PROV-REG-CULT & YES & $\begin{array}{l}\text { SudhanyakhaliIsland-Gosaba } \\
\text { Island-East Kolkata Wetland }\end{array}$ & Wetland \\
\hline Hosseini et al., 2019 [186] & Iran & MIX & MAN & PROV-REG & EXP & Various & Groundwater \\
\hline Kacem et al., 2019 [187] & Morocco & MIX & IMPACT-VUL & PROV-REG & EXP & Draden basin & River \\
\hline Karabulut et al., 2019 [188] & $\begin{array}{l}\text { Mediterranean } \\
\text { region }\end{array}$ & DIS & MAN & PROV-REG & EXP & $\begin{array}{l}\text { Theoretical-Mediterranean } \\
\text { region }\end{array}$ & Theoretical \\
\hline Yun et al., 2019 [189] & Korea & HIER & MAN & PROV-REG-CULT & EXP & Various & Wetland \\
\hline Dowlatabadi et al., 2020 [150] & Iran-Irak-Turkey & MIX & $\mathrm{CON}$ & PROV-REG & YES & $\begin{array}{l}\text { Tigris and Karkheh rivers and } \\
\text { the Hawizeh/Hoor-Al-Azim } \\
\text { wetland }\end{array}$ & Wetland \\
\hline
\end{tabular}




\section{Conclusions}

FES represent a source of conflict around the world, especially in countries where this resource is scarce. Moreover, their management becomes extremely complicated once waterbodies cross different regions and countries, involving different governments, cultures, and administrations-often already in conflict over other issues.

Multi-criteria models are very useful in helping to identify these conflicts and tackle them effectively. In addition, they provide a key tool for managing water-related decisionmaking processes by incorporating the preferences of different agents and dealing with conflicts from the outset.

Between 2000 and 2005, there was a marked increase in the number of studies addressing sustainable water management from an integrated perspective, jointly considering all of the ecosystem services and incorporating the preferences of all the relevant stakeholders. However, such articles are becoming less common, giving way to studies that separately explore strictly ecological functions of water and, to a lesser extent, provisioning services. This trend is reflected in the $78.88 \%$ reduction in studies involving participation since 2006 .

In contrast, the substantial and serious loss of wetlands over the past decade has prompted an increase in studies focusing on these sites, which aimed at preserving their supporting and regulating functions. They are mainly concerned with solving problems of conservation management and analysing impact or vulnerability.

Articles dealing with provisioning, cultural, and supporting services individually do not involve stakeholder participation. Specifically, provisioning services are generally addressed by calling on the participation of experts or water negotiators. While analyses of the regulating ecosystem services of freshwater ecosystems have involved participation to a greater extent than other groups of studies, there is still a higher proportion of studies not involving stakeholders in decision-making processes.

International diplomacy should incorporate conflict management from the outset, while taking into account the interests of different stakeholder groups from the early stages of public policy planning, mainly in transboundary sites where conflicts are particularly challenging.

Studies on water management and conservation that reflect its essence from an ecosystem service point of view should be promoted; there is a need for studies that take an integrated approach to exploring the interrelationships between hydrology, landscapes, ecology, and humans. This scientific approach should be complemented with an integrated framework that is supported by legal and normative strategies of land and landscape management, to ensure the viability and sustainability of these initiatives.

Such an integrated approach should be broadly encouraged, seeking to involve all relevant stakeholders that are affected by national and international regulations and policies on water management. It is recommended that experts, governments, and water negotiators should continue to participate, but efforts should also be made to ensure that the preferences of the main stakeholder groups are represented in decision-making processes, in order to underscore their legitimacy. A particular emphasis should be placed on the concept of sustainability welfare, prudence, and justice. Given the expansive scope of this approach, it becomes possible to simultaneously achieve goals relating to the conservation of nature and peace, thereby helping to improve the wellbeing of humanity.

It is relevant to highlight that the decrease of participation found in this analysis is exclusively related to MCDM techniques. This does not correspond to efforts to apply participatory approaches in the implementation of water policy. In Europe, for example, the Water Framework Directive sets requirements to stakeholder participation in its implementation which has been followed by all Member States. In this sense, MCDM can contribute to the improvement of the implementation of European water policy. Moreover, it would be interesting to simultaneously combine experts and stakeholders in participatory initiatives, making these processes advance towards higher quality and integrated solutions.

From a methodological perspective, future research lines should be oriented to specific reviews separately analysing the function and usefulness of MCDM exclusively providing 
information and MCDM providing tools to the implementation of decision-making processes, as well as MCDM providing solutions to conflicts or guiding negotiation processes (decision support systems).

Author Contributions: Conceptualization, M.d.C.-P., P.F.M., A.P.Z. and J.C.A.; methodology, M.d.C.-P. and J.C.A.; writing—original draft preparation, M.d.C.-P.; writing—review and editing, J.C.A.; supervision, J.C.A.; project administration, P.F.M. and A.P.Z.; funding acquisition, A.P.Z. All authors have read and agreed to the published version of the manuscript.

Funding: This research received no external funding.

Institutional Review Board Statement: Not applicable.

Informed Consent Statement: Not applicable.

Data Availability Statement: Not applicable.

Acknowledgments: The authors thanks the UNESCO UNED-URJC Chair in Water and Peace institutional coverage to the development of this study.

Conflicts of Interest: The authors declare no conflict of interest.

\section{References}

1. Martin-Ortega, J.; Ferrier, R.C.; Gordon, I.J.; Khan, S. Water Ecosystem Services: A Global Perspective; UNESCO Publishing: Paris, France, 2015.

2. Hoekstra, A.Y.; Wiedmann, T.O. Humanity's unsustainable environmental footprint. Science 2014, 344, 1114-1117. [CrossRef] [PubMed]

3. Ormerod, S.J.; Dobson, M.; Hildrew, A.G.; Townsend, C. Multiple stressors in freshwater ecosystems. Freshwater Biol. 2010, 55, 1-4. [CrossRef]

4. Strayer, D.L.; Dudgeon, D. Freshwater biodiversity conservation: Recent progress and future challenges. J. N. Am. Benthol. Soc. 2010, 29, 344-358. [CrossRef]

5. United Nations. 2019. Available online: https://www.un.org/en/sections/issues-depth/water/ (accessed on 6 December 2020).

6. UN General Assembly. Transforming our World: The 2030 Agenda for Sustainable Development, 21 October 2015, A/RES/70/1. Available online: https:/ / www.refworld.org/docid/57b6e3e44.html (accessed on 15 February 2021).

7. The Economist Intelligence Unit Limited. Blue Peace Index 2019. Available online: https://bluepeaceindex.eiu.com/\#/ (accessed on 8 December 2020).

8. Pérez Zabaleta, A.; Gracia de Rentería, P.; Ballesteros, M.; Pérez Foguet, A.; Ezbakhe, F.; Guerra-Librero, A. Analysis of Renewal Investment Needs of the Urban Water Cycle in Spain; UNED: Madrid, Spain, 2020.

9. Pérez Zabaleta, A.; Gracia de Rentería, P.; Escalera-Izquierdo, G. Circular economy as a tool to mitigate the effects of climate change on water resources: The case of Spain. DYNA 2020, 95, 611-614.

10. Gaget, E.; Le Viol, I.; Pavón-Jordán, D.; Cazalis, V.; Kerbiriou, C.; Jiguet, F.; Abdou, W.A.I. Assessing the effectiveness of the Ramsar Convention in preserving wintering waterbirds in the Mediterranean. Biol. Conserv. 2020, 243, 108485. [CrossRef]

11. Kingsford, R.T.; Biggs, H.C.; Pollard, S.R. Strategic adaptive management in freshwater protected areas and their rivers. Biol. Conserv. 2011, 144, 1194-1203. [CrossRef]

12. Suski, C.D.; Cooke, S.J. Conservation of aquatic resources through the use of freshwater protected areas: Opportunities and challenges. Biodivers. Conserv. 2007, 16, 2015-2029. [CrossRef]

13. Chellaney, B. Water, Peace, and War: Confronting the Global Water Crisis; Rowman \& Littlefield: Lanham, MD, USA, 2013.

14. Marttunen, M.; Hämäläinen, R.P. The decision analysis interview approach in the collaborative management of a large regulated water course. Environ. Manag. 2008, 42, 1026. [CrossRef]

15. De Castro-Pardo, M.; Urios, V. A critical review of multi-criteria decision making in protected areas. Econ. Agrar. Recurs. Nat.-Agricult. Resour. Econ. 2017, 16, 89-109. [CrossRef]

16. Kaya, A.; Bettinger, P.; Boston, K.; Akbulut, R.; Ucar, Z.; Siry, J.; Merry, K.; Cieszewski, C. Optimisation in forest Management. Curr. For. Rep. 2016, 2, 1-17. [CrossRef]

17. Diaz-Balteiro, L.; González-Pachón, J.; Romero, C. Measuring systems sustainability with multi-criteria methods: A critical review. Eur. J. Operat. Res. 2017, 258, 607-616. [CrossRef]

18. Nordström, E.M.; Nieuwenhuis, M.; Başkent, E.Z.; Biber, P.; Black, K.; Borges, J.G.; Zoccatelli, D. Forest decision support systems for the analysis of ecosystem services provisioning at the landscape scale under global climate and market change scenarios. Eur. J. For. Res. 2019, 138, 561-581. [CrossRef]

19. Hajkowicz, S.; Collins, K. A review of multiple criteria analysis for water resource planning and management. Water Resour. Manag. 2007, 21, 1553-1566. [CrossRef]

20. Herath, G. Multi-criteria decision making in water resources planning: What does the evidence show. Rev. Manag. Innov. Creat. 2010, 3, 38-55. 
21. Cai, X.; Lasdon, L.; Michelsen, A.M. Group decision making in water resources planning using multiple objective analysis. J. Water Resour. Plan. Manag. 2004, 130, 4-14. [CrossRef]

22. Mimi, Z.A.; Sawalhi, B.I. A decision tool for allocating the waters of the Jordan River Basin between all riparian parties. Water Resour. Manag. 2003, 17, 447-461. [CrossRef]

23. Snyder, H. Literature review as a research methodology: An overview and guidelines. J. Bus. Res. 2019, 104, 333-339. [CrossRef]

24. Templier, M.; Paré, G. A framework for guiding and evaluating literature reviews. Commun. Assoc. Inform. Syst. 2015, 37, 112-137. [CrossRef]

25. Millennium Ecosystem Assessment. Ecosystems and Human Well-Being: Synthesis; Island Press: Washington, DC, USA, 2005.

26. Zimmerman, H.J. Fuzzy programming and linear programming with several objective functions. Fuzzy Sets Syst. 1978, 1, 45-55. [CrossRef]

27. Saaty, T.L. Axiomatic foundation of the analytic hierarchy process. Manag. Sci. 1986, 32, 841-855. [CrossRef]

28. Ortiz-Urbina, E.; González-Pachón, J.; Diaz-Balteiro, L. Decision-making in forestry: A review of the hybridisation of multiple criteria and group decision-making methods. Forests 2019, 10, 375. [CrossRef]

29. Roy, B. Classement et choix en présence de points de vue multiples (La méthode de ELECTRE). Rev. Franc. Inform. Rech. Opération. $1968,6,57-75$.

30. Brans, J.P.; Vincke, P.; Mareschal, B. Howtoselect andhow torank projects: The PROMETHEE methods. Eur. J. Operat. Res. 1986, 24, 228-238. [CrossRef]

31. Mendoza, G.A.; Martins, H. Multi-criteria decision analysis in natural resource management: A critical review of methods and new modelling paradigms. For. Ecol. Manag. 2006, 230, 1-22. [CrossRef]

32. Keeney, R.L.; Raiffa, H. Decisions with Multiple Objectives: Preferences and Value Trade-Offs; John Wiley and Sons: New York, NY, USA, 1976.

33. Levin, S.A. Encyclopedia of Biodiversity, 2nd ed.; Reference Work; Elsevier: Amsterdam, The Netherlands, 2013.

34. De la Fuente Fernández, S. Aplicaciones de la Chi-Cuadrado: Tablas de Contingencia. Homogeneidad, Dependencia e Independencia; UAM: Madrid, Spain, 2016.

35. Ugoni, A.; Walker, B.F. The Chi square test: An introduction. COMSIG Rev. 1995, 4, 61. [PubMed]

36. Ramsar Convention. Global Wetland Outlook: State of the World's Wetlands and their Services to People; Ramsar Convention: Ramsar, Iran; Gland, Switzerland, 2018.

37. De Castro-Pardo, M.; Azevedo, J.C. A Goal Programming Model to Guide Decision-Making Processes towards Conservation Consensuses. Sustainability 2021, 13, 1959. [CrossRef]

38. Jaber, J.O.; Mohsen, M.S. Evaluation of non-conventional water resources supply in Jordan. Desalination 2001, 136, 83-92. [CrossRef]

39. Chowdhury, A.; Jha, M.K.; Chowdary, V.M. Delineation of groundwater recharge zones and identification of artificial recharge sites in West Medinipur district, West Bengal, using RS, GIS and MCDM techniques. Environ. Earth Sci. 2010, 59, 1209. [CrossRef]

40. Machiwal, D.; Jha, M.K.; Mal, B.C. Assessment of groundwater potential in a semi-arid region of India using remote sensing, GIS and MCDM techniques. Water Resour. Manag. 2011, 25, 1359-1386. [CrossRef]

41. Machiwal, D.; Rangi, N.; Sharma, A. Integrated knowledge-and data-driven approaches for groundwater potential zoning using GIS and multi-criteria decision making techniques on hard-rock terrain of Ahar catchment, Rajasthan, India. Environ. Earth Sci. 2015, 73, 1871-1892. [CrossRef]

42. Çelik, R. Evaluation of groundwater Potential by GIS-Based Multicriteria Decision Making as a Spatial Prediction Tool: Case Study in the Tigris river Batman-Hasankeyf Sub-Basin, Turkey. Water 2019, 11, 2630. [CrossRef]

43. Rana, V.K.; Suryanarayana, T.M.V. GIS-based multi criteria decision making method to identify potential runoff storage zones within watershed. Ann. GIS 2020, 26, 149-168. [CrossRef]

44. Swetha, T.V.; Gopinath, G.; Thrivikramji, K.P.; Jesiya, N.P. Geospatial and MCDM tool mix for identification of potential groundwater prospects in a tropical river basin, Kerala. Environ. Earth Sci. 2017, 76, 428. [CrossRef]

45. Prato, T. Adaptive management of large rivers with special reference to the Missouri river. J. Am. Water Resour. Assoc. 2003, 39 , 935-946. [CrossRef]

46. Hyde, K.M.; Maier, H.R.; Colby, C.B. Reliability-based approach to multicriteria decision analysis for water resources. J. Water Resour. Plan. Manag. 2004, 130, 429-438. [CrossRef]

47. Arriaza, M.; Gómez-Limón, J.A.; Upton, M. Local water markets for irrigation in southern Spain: A multicriteria approach. Austr. J. Agricult. Resour. Econ. 2002, 46, 21-43. [CrossRef]

48. López-Baldovin, M.J.; Gutiérrez-Martin, C.; Berbel, J. Multicriteria and multiperiod programming for scenario analysis in Guadalquivir river irrigated farming. J. Operat. Res. Soc. 2006, 57, 499-509. [CrossRef]

49. Mysiak, J.; Giupponi, C.; Rosato, P. Towards the development of a decision support system for water resource management. Environ. Model. Softw. 2005, 20, 203-214. [CrossRef]

50. Roozbahani, A.; Ebrahimi, E.; Banihabib, M.E. A framework for ground water management based on Bayesian network and MCDM techniques. Water Resour. Manag. 2018, 32, 4985-5005. [CrossRef]

51. Zarghami, M.; Szidarovszky, F. Stochastic-fuzzy multi criteria decision making for robust Water Resource Management. Stochast. Environ. Res. Risk Assess. 2009, 23, 329-339. [CrossRef] 
52. Estalaki, S.M.; Kerachian, R.; Nikoo, M.R. Developing water quality management policies for the Chitgar urban Lake: Application of fuzzy social choice and evidential reasoning methods. Environ. Earth Sci. 2016, 75, 404. [CrossRef]

53. Nayak, R.C.; Panda, R.K. Integrated management of a canal command in a River Delta using multiobjective techniques. Water Resour. Manag. 2001, 15, 383-401. [CrossRef]

54. Karnib, A. An approach to elaborate priority preorders of water resources projects based on multi-criteria evaluation and fuzzy sets analysis. Water Resour. Manag. 2004, 18, 13-33. [CrossRef]

55. McPhee, J.; Yeh, W.W.G. Multi-objective optimisation for sustainable groundwater management in semi-arid regions. J. Water Resour. Plan. Manag. 2004, 130, 490-497. [CrossRef]

56. Srdjevic, B.; Medeiros, Y.D.P.; Faria, A.S. An objective multi-criteria evaluation of water management scenarios. Water Resour. Manag. 2004, 18, 35-54. [CrossRef]

57. Zarghaami, R. Integrated Water Resour. Manag. in Polrud Irrigation system. Water Resour. Manag. 2006, 20, 215-225. [CrossRef]

58. Raju, K.S.; Vasan, A. Multi attribute utility theory for irrigation. Water Resour. Manag. 2007, 21, 717-728. [CrossRef]

59. Gómez-Limón, J.A.; Riesgo, L. Alternative approaches to the construction of a composite indicator of agricultural sustainability: An application to irrigated agriculture in the Duero basin in Spain. J. Environ. Manag. 2009, 90, 3345-3362. [CrossRef]

60. Opricovic, S. Fuzzy VIKOR with an application to water resources planning. Exp. Syst. Applicat. 2011, 38, 12983-12990. [CrossRef]

61. Zeng, Y.; Li, J.; Cai, Y.; Tan, Q. Equitable and reasonable freshwater allocation based on a multi-criteria decision making approach with hydrologically constrained bankruptcy rules. Ecol. Indicat. 2017, 73, 203-213. [CrossRef]

62. Arabameri, A.; Rezaei, K.; Cerda, A.; Lombardo, L.; Rodrigo-Comino, J. GIS-based groundwater potential mapping in Shahroud plain, Iran. A comparison among statistical (bivariate and multivariate), data mining and MCDM approaches. Sci. Total Environ. 2019, 658, 160-177. [CrossRef]

63. Bera, K.; Banik, P. Multi-criteria decision analysis (MCDA) for surface water management plan, a case study of Kansachara sub-watershed, West Bengal, India. Water Supply 2019, 19, 2156-2162. [CrossRef]

64. Arabameri, A.; Lee, S.; Tiefenbacher, J.P.; Ngo, P.T.T. Novel Ensemble of MCDM-Artificial Intelligence Techniques for groundwaterPotential Mapping in Arid and Semi-Arid Regions (Iran). Remote Sens. 2020, 12, 490. [CrossRef]

65. Daneshvar, F.; Nejadhashemi, A.P.; Adhikari, U.; Elahi, B.; Abouali, M.; Herman, M.R.; Rohn, B.G. Evaluating the significance of wetland restoration scenarios on phosphorus removal. J. Environ. Manag. 2017, 192, 184-196. [CrossRef] [PubMed]

66. Janssen, R.; Goosen, H.; Verhoeven, M.L.; Verhoeven, J.T.; Omtzigt, A.Q.A.; Maltby, E. Decision support for integrated wetland management. Environ. Model. Softw. 2005, 20, 215-229. [CrossRef]

67. Brouwer, R.; Ek, R.V. Integrated ecological, economic and social impact assessment of alternative flood control policies in the Netherlands. Ecol. Econ. 2004, 50, 1-21. [CrossRef]

68. Levy, J.K. Multiple criteria decision making and decision support systems for flood risk management. Stochast. Environ. Res. Risk Assess. 2005, 19, 438-447. [CrossRef]

69. Kenyon, W. Evaluating flood risk management options in Scotland: A participant-led multi-criteria approach. Ecol. Econ. 2007, 64, 70-81. [CrossRef]

70. Levy, J.K.; Hartmann, J.; Li, K.W.; An, Y.; Asgary, A. Multi-criteria decision support systems for flood hazard mitigation and emergency response in urban watersheds 1. J. Am. Water Resour. Assoc. 2007, 43, 346-358. [CrossRef]

71. Perrone, A.; Inam, A.; Albano, R.; Adamowski, J.; Sole, A. A participatory system dynamics modeling approach to facilitate collaborative flood risk management: A case study in the Bradano river (Italy). J. Hydrol. 2020, 580, 124354. [CrossRef]

72. Rohde, S.; Hostmann, M.; Peter, A.; Ewald, K.C. Room for rivers: An integrative search strategy for floodplain restoration. Landsc. Urban Plan. 2006, 78, 50-70. [CrossRef]

73. Randhir, T.; Shriver, D.M. Deliberative valuation without prices: A multiattribute prioritization for watershed ecosystem management. Ecol. Econ. 2009, 68, 3042-3051. [CrossRef]

74. Gross, C.; Hagy, J.D., III. Attributes of successful actions to restore lakes and estuaries degraded by nutrient pollution. J. Environ. Manag. 2017, 187, 122-136. [CrossRef] [PubMed]

75. Arondel, C.; Girardin, P. Sorting cropping systems on the basis of their impact on groundwater quality. Eur. J. Operat. Res. 2000, 127, 467-482. [CrossRef]

76. Chuntian, C.; Chau, K.W. Three-person multi-objective conflict decision in reservoir flood control. Eur. J. Operat. Res. 2002, 142, 625-631. [CrossRef]

77. Wang, X.L.; Ning, L.M.; Hu, W.B. Application of analytic hierarchy process to assessing the ecological vulnerability of wetlands in the Jianghan Plain. Chin. Geogr. Sci. 2003, 13, 272-276. [CrossRef]

78. Bana e Costa, C.A.; Da Silva, P.A.; Correia, F.N. Multicriteria evaluation of flood control measures: The case of Ribeira do Livramento. Water Resour. Manag. 2004, 18, 263-283. [CrossRef]

79. Herath, G. Incorporating community objectives in improved wetland management: The use of the analytic hierarchy process J. Environ. Manag. 2004, 70, 263-273. [CrossRef] [PubMed]

80. Olenick, K.L.; Wilkins, N.; Conner, J.R. Increasing off-site water yield and grassland bird habitat in Texas through brush treatment practices. Ecol. Econ. 2004, 49, 469-484. [CrossRef]

81. Tzionas, P.; Ioannidou, I.A.; Paraskevopoulos, S. A hierarchical fuzzy decision support system for the environmental rehabilitation of Lake Koronia, Greece. Environ. Manag. 2004, 34, 245-260. [CrossRef] [PubMed] 
82. Almasri, M.N.; Kaluarachchi, J.J. Multi-criteria decision analysis for the optimal management of nitrate contamination of aquifers. J. Environ. Manag. 2005, 74, 365-381. [CrossRef] [PubMed]

83. Lee, C.S.; Chang, S.P. Interactive fuzzy optimization for an economic and environmental balance in a river system. Water Res. 2005, 39, 221-231. [CrossRef] [PubMed]

84. Elshorbagy, A. Multicriterion decision analysis approach to assess the utility of watershed modeling for management decisions. Water Resour. Res. 2006, 42. [CrossRef]

85. Liu, C.; Frazier, P.; Kumar, L.; Macgregor, C.; BLAK, N. Catchment-wide wetland assessment and prioritization using the multi-criteria decision-making method TOPSIS. Environ. Manag. 2006, 38, 316-326. [CrossRef] [PubMed]

86. Li, R. Dynamic assessment on regional eco-environmental quality using AHP-statistics model—A case study of Chaohu Lake Basin. Chin. Geogr. Sci. 2007, 17, 341-348. [CrossRef]

87. Qin, X.S.; Huang, G.H.; Chakma, A.; Nie, X.H. A MCDM-based expert system for climate-change impact assessment and adaptation planning. A case study for the Georgia Basin, Canada. Exp. Syst. Applicat. 2008, 34, 2164-2179. [CrossRef]

88. Olu-Owolabi, B.I.; Agunbiade, F.O.; Oseghe, E.O.; Adebowale, K.O. Fuzzy logic modeling of contamination degree of Ni and V metal species in sediments from the crude oil prospecting area of the Ondo coast, Nigeria. Human Ecol. Risk Assess. Int. J. 2012, 18, 902-918. [CrossRef]

89. Sun, Y.G.; Zhao, D.Z.; Zhang, F.S.; Wei, B.Q.; Chu, J.L.; Su, X. Spatiotemporal dynamic fuzzy evaluation of wetland environmental pollution risk in Dayang Estuary of Liaoning Province, Northeast China based on remote sensing. Ying Yong Sheng Tai Xue Bao J. Appl. Ecol. 2012, 23, 3180-3186.

90. Wu, J.; Wu, J.; Wang, X.; Zhong, M. Securing water for wetland conservation: A comparative analysis of policy options to protect a national reserve in China. J. Environ. Manag. 2012, 94, 102-111. [CrossRef]

91. Sener, E.; Davraz, A. Assessment of GRO vulnerability based on a modified DRASTIC model, GIS and an analytic hierarchy process (AHP) method: The case of Egirdir lake basin (Isparta, Turkey). Hydrogeol. J. 2013, 21, 701-714. [CrossRef]

92. Lee, G.; Jun, K.S.; Chung, E.S. Robust spatial flood vulnerability assessment for Han river using fuzzy TOPSIS with $\alpha$-cut level set. Exp. Syst. Applicat. 2014, 41, 644-654. [CrossRef]

93. Malekmohammadi, B.; Blouchi, L.R. Ecological risk assessment of wetland ecosystems using multi criteria decision making and geographic information system. Ecol. Indicat. 2014, 41, 133-144. [CrossRef]

94. Chatterjee, K.; Bandyopadhyay, A.; Ghosh, A.; Kar, S. Assessment of environmental factors causing wetland degradation, using Fuzzy Analytic Network Process: A case study on Keoladeo National Park, India. Ecol. Model. 2015, 316, 1-13. [CrossRef]

95. McVittie, A.; Norton, L.; Martin-Ortega, J.; Siameti, I.; Glenk, K.; Aalders, I. Operationalizing an ecosystem services-based approach using Bayesian Belief Networks: An application to riparian buffer strips. Ecol. Econ. 2015, 110, 15-27. [CrossRef]

96. Meraj, G.; Romshoo, S.A.; Yousuf, A.R.; Altaf, S.; Altaf, F. Assessing the influence of watershed characteristics on the flood vulnerability of Jhelum basin in Kashmir Himalaya. Nat. Hazards 2015, 77, 153-175. [CrossRef]

97. Shafiee, M.; Saffarian, S.; Zaredar, N. Risk assessment of human activities on protected areas: A case study. Human Ecol. Risk Assess. Int. J. 2015, 21, 1462-1478. [CrossRef]

98. Walker, D.; Jakovljević, D.; Savić, D.; Radovanović, M. Multi-criterion water quality analysis of the Danube River in Serbia: A visualisation approach. Water Res. 2015, 79, 158-172. [CrossRef] [PubMed]

99. Abd-El Monsef, H.; Hassan, M.A.; Shata, S. Using spatial data analysis for delineating existing mangroves stands and siting suitable locations for mangroves plantation. Comp. Electron. Agricult. 2017, 141, 310-326. [CrossRef]

100. Duodu, G.O.; Ogogo, K.N.; Mummullage, S.; Harden, F.; Goonetilleke, A.; Ayoko, G.A. Source apportionment and risk assessment of PAHs in Brisbane RIV sediment, Australia. Ecol. Indicat. 2017, 73, 784-799. [CrossRef]

101. Man, W.D.; Liu, M.Y.; Wang, Z.M.; Mao, H.; Tian, Y.L.; Jia, M.M.; Ren, C.Y. Dynamics of habitat suitability for waterfowls from 1990 to 2015 in the ecological function zone of Sanjiang Plain, Northeast China. Ying Yong Sheng Tai Xue Bao J. Appl. Ecol. 2017, $28,4083$.

102. Malekmohammadi, B.; Jahanishakib, F. Vulnerability assessment of wetland landscape ecosystem services using driver-pressurestate-impact-response (DPSIR) model. Ecol. Indicat. 2017, 82, 293-303. [CrossRef]

103. Rather, M.A.; Kumar, J.S.; Farooq, M.; Rashid, H. Assessing the influence of watershed characteristics on soil erosion susceptibility of Jhelum basin in Kashmir Himalayas. Arab. J. Geosci. 2017, 10, 59. [CrossRef]

104. Golbarg, F.; Nabi Bidhendi, G.; Hoveidi, H. Environ. Manag. of oil pipelines risks in the wetland areas by Delphi and MCDM techniques: Case of Shadegan international wetland, Iran. Pollution 2018, 4, 195-210.

105. Maleki, S.; Soffianian, A.R.; Koupaei, S.S.; Pourmanafi, S.; Saatchi, S. Wetland restoration prioritizing, a tool to reduce negative effects of drought; An application of multicriteria-spatial decision support system (MC-SDSS). Ecol. Eng. 2018, 112, 132-139. [CrossRef]

106. Rahdari, V.; Soffianian, A.R.; Pourmanafi, S.; Ghaiumi, M.H.; Mosadeghi, R.; Amiri, F. A multi-objective approach for land conservation capability evaluation using multi-criterion evaluation models. Appl. Ecol. Environ. Res. 2018, 16, $1353-1367$. [CrossRef]

107. Arabameri, A.; Cerda, A.; Rodrigo-Comino, J.; Pradhan, B.; Sohrabi, M.; Blaschke, T.; Tien Bui, D. Proposing a novel predictive technique for gully erosion susceptibility mapping in arid and semi-arid regions (Iran). Remote Sens. 2019, 11, 2577. [CrossRef]

108. Bid, S.; Siddique, G. Human risk assessment of Panchet dam in India using TOPSIS and WASPAS multi-criteria decision-making (MCDM) methods. Heliyon 2019, 5, e01956. [CrossRef] [PubMed] 
109. De Souza Fraga, M.; da Silva, D.D.; Elesbon, A.A.A.; Guedes, H.A.S. Methodological proposal for the allocation of water quality monitoring stations using strategic decision analysis. Environ. Monit. Assess. 2019, 191, 776. [CrossRef] [PubMed]

110. Ghosh, S.; Das, A. Urban expansion induced vulnerability assessment of East Kolkata wetland using Fuzzy MCDM method. Remote Sens. Applicat. Soc. Environ. 2019, 13, 191-203. [CrossRef]

111. Li, S.; Chen, X.; Singh, V.P.; He, Y.; Bai, X. An improved index for water quality evaluation in an estuary region: A case study in the Eastern Pearl River Delta, China. Water Policy 2019, 21, 310-325. [CrossRef]

112. Roy, R.; Majumder, M. Assessment of water quality trends in Loktak Lake, Manipur, India. Environ. Earth Sci. 2019, 78, 383. [CrossRef]

113. Xu, X.; Sheng, D.; Li, G.; Chen, X.; Wang, X.; Xiao, C.; Hu, C. Comprehensive Assessment of the Water Ecological Security of the Xiangjiang River Basin Based on Physico-chemistry and Organisms Indices. Appl. Ecol. Environ. Res 2019, 17, 4547-4574. [CrossRef]

114. Akay, H.; Koçyiğit, M.B. Flash flood potential prioritization of sub-basins in an ungauged basin in Turkey using traditional multi-criteria decision-making methods. Soft Comp. 2020, 24, 14251-14263. [CrossRef]

115. Alamanos, A.; Papaioannou, G. A GIS Multi-Criteria Analysis Tool for a Low-Cost, Preliminary Evaluation of wetland Effectiveness for Nutrient Buffering at Watershed Scale: The Case Study of Grand River, Ontario, Canada. Water 2020, $12,3134$. [CrossRef]

116. Arabameri, A.; Tiefenbacher, J.P.; Blaschke, T.; Pradhan, B.; Tien Bui, D. Morphometric analysis for soil erosion susceptibility mapping using novel gis-based ensemble model. Remote Sens. 2020, 12, 874. [CrossRef]

117. Bhattacharya, R.K.; Chatterjee, N.D.; Das, K. Sub-basin prioritization for assessment of soil erosion susceptibility in Kangsabati, a plateau basin: A comparison between MCDM and SWAT models. Sci. Total Environ. 2020, 734, 139474. [CrossRef] [PubMed]

118. Ghaleno, M.R.D.; Meshram, S.G.; Alvandi, E. Pragmatic approach for prioritization of flood and sedimentation hazard potential of watersheds. Soft Comput. 2020, 24, 15701-15714. [CrossRef]

119. Ghosh, S.; Das, A. Wetland conversion risk assessment of East Kolkata Wetland: A Ramsar site using random forest and support vector machine model. J. Clean. Prod. 2020, 275, 123475. [CrossRef]

120. Popović, M.J.; Gušavac, B.Š.A.; Katić, A.S. Multiattribute Methods as a Means for Solving Ecological Problems in Water Resources-Lake Pollution. In Advances in Operational Research in the Balkans; Springer: Cham, Switzeland, 2020 ; pp. 77-94.

121. Sarkar, K.; Majumder, M. Application of AHP-based water quality index for quality monitoring of peri-urban watershed. Environ. Dev. Sustain. 2020, 23, 1780-1798. [CrossRef]

122. Souissi, D.; Zouhri, L.; Hammami, S.; Msaddek, M.H.; Zghibi, A.; Dlala, M. GIS-based MCDM-AHP modeling for flood susceptibility mapping of arid areas, southeastern Tunisia. Geocarto Int. 2020, 35, 991-1017. [CrossRef]

123. Sun, R.; Gong, Z.; Gao, G.; Shah, A.A. Comparative analysis of Multi-Criteria Decision-Making methods for flood disaster risk in the Yangtze River Delta. Int. J. Dis. Risk Reduct. 2020, 51, 101768. [CrossRef]

124. Yang, Z.; Wang, Y. The cloud model based stochastic multi-criteria decision making technology for river health assessment under multiple uncertainties. J. Hydrol. 2020, 581, 124437. [CrossRef]

125. Zhang, H.; Gu, C.L.; Gu, L.W.; Zhang, Y. The evaluation of tourism destination competitiveness by TOPSIS \& information entropy-A case in the Yangtze river Delta of China. Tour. Manag. 2011, 32, 443-451.

126. Tang, C.; Zheng, Q.; Ng, P. A Study on the Coordinative Green Development of Tourist Experience and Commercialization of Tourism at Cultural Heritage Sites. Sustainability 2019, 11, 4732. [CrossRef]

127. Aiping, Z.; Linsheng, Z.; Yong, X.; Lijuan, D.; Bin, Z. Identifying and mapping wetland-based ecotourism areas in the First Meander of the Yellow River: Incorporating tourist preferences. J. Resour. Ecol. 2015, 6, 21-29. [CrossRef]

128. Biglarfadafan, M.; Danehkar, A.; Pourebrahim, S.; Shabani, A.A.; Moeinaddini, M. Application of strategic fuzzy assessment for environmental planning; case of bird watch zoning in wetlands. Open J. Geol. 2016, 6, 1380. [CrossRef]

129. Erfani, M.; Afrougheh, S.; Ardakani, T.; Sadeghi, A. Tourism positioning using decision support system (case study: ChahnimeZabol, Iran). Environ. Earth Sci. 2015, 74, 3135-3144. [CrossRef]

130. Balist, J.; Heydarzadeh, H.; Salehi, E. Modeling, evaluation, and zoning of Marivan county ecotourism potential using fuzzy logic, FAHP, and TOPSIS. Geogr. Pannon. 2019, 23, 47-63. [CrossRef]

131. Maghsoudi, M.; Moradi, A.; Moradipour, F.; Nezammahalleh, M.A. Geotourism Development in World Heritage of the Lut Desert. Geoheritage 2019, 11, 501-516. [CrossRef]

132. Qureshi, M.E.; Harrison, S.R. A decision support process to compare Riparian revegetation options in Scheu Creek catchment in North Queensland. J. Environ. Manag. 2001, 62, 101-112. [CrossRef]

133. Eliasson, Å.; Rinaldi, F.M.; Linde, N. Multicriteria decision aid in supporting decisions related to groundwater protection. Environ. Manag. 2003, 32, 589-601. [CrossRef]

134. Choulak, M.; Marage, D.; Gisbert, M.; Paris, M.; Meinard, Y. A meta-decision-analysis approach to structure operational and legitimate environmental policies-With an application to wetland prioritization. Sci. Total Environ. 2019, 655, 384-394. [CrossRef] [PubMed]

135. Chen, V.Y.C.; Lin, J.C.L.; Tzeng, G.H. Assessment and improvement of wetlands environmental protection plans for achieving sustainable development. Environ. Res. 2019, 169, 280-296. [CrossRef] [PubMed]

136. Saha, T.K.; Pal, S. Exploring physical wetland vulnerability of Atreyee river basin in India and Bangladesh using logistic regression and fuzzy logic approaches. Ecol. Indicat. 2019, 98, 251-265. [CrossRef] 
137. Talukdar, S.; Pal, S.; Chakraborty, A.; Mahato, S. Damming effects on trophic and habitat state of riparian wetlands and their spatial relationship. Ecol. Indicat. 2020, 118, 106757. [CrossRef]

138. Buruso, F.H. Habitat suitability analysis for hippopotamus (H. amphibious) using GIS and remote sensing in Lake Tana and its environs, Ethiopia. Environ. Syst. Res. 2018, 6, 6. [CrossRef]

139. Wu, H.J.; Dan, X.Q.; Liu, S.H.; Huang, Y.; Shu, Y.; Cao, H.; Wu, Z.B. Protection value evaluation of national wetlands parks in Hunan province, China. J. Appl. Ecol. 2017, 28, 239-249.

140. Jafari Shalamzari, M.; Zhang, W.; Gholami, A.; Zhang, Z. Runoff Harvesting Site Suitability Analysis for Wildlife in Sub-Desert Regions. Water 2019, 11, 1944. [CrossRef]

141. Dong, Z.; Wang, Z.; Liu, D.; Li, L.; Ren, C.; Tang, X.; Liu, C. Assessment of habitat suitability for waterbirds in the West Songnen Plain, China, using remote sensing and GIS. Ecol. Eng. 2012, 55, 94-100. [CrossRef]

142. Kozlov, A.; Kozlova, M.; Skorik, N. A simple harmonic model for FAPAR temporal dynamics in the wetlands of the Volga-Akhtuba floodplain. Remote Sens. 2016, 8, 762. [CrossRef]

143. Qiu, Z.; Dosskey, M.G.; Kang, Y. Choosing between alternative placement strategies for conservation buffers using Borda count. Landsc. Urban Plan. 2016, 153, 66-73. [CrossRef]

144. Xue, S.; Sun, T.; Zhang, H.; Shao, D. Suitable habitat mapping in the Yangtze River Estuary influenced by land reclamations. Ecol. Eng. 2016, 97, 64-73. [CrossRef]

145. Qi, L.; Huang, J.; Huang, Q.; Gao, J.; Wang, S.; Guo, Y. Assessing Aquatic Ecological Health for Lake Poyang, China: Part I Index Development. Water 2018, 10, 943. [CrossRef]

146. Gregory, R.; Wellman, K. Bringing stakeholder values into environmental policy choices: A community-based estuary case study. Ecol. Econ. 2001, 39, 37-52. [CrossRef]

147. Azarnivand, A.; Hashemi-Madani, F.S.; Banihabib, M.E. Extended fuzzy analytic hierarchy process approach in water and Environ. Manag. (case study: Lake Urmia Basin, Iran). Environ. Earth Sci. 2015, 73, 13-26. [CrossRef]

148. Derak, M.; Cortina, J.; Taiqui, L. Integration of stakeholder choices and multi-criteria analysis to support land use planning in semiarid areas. Land Use Policy 2017, 64, 414-428. [CrossRef]

149. Weng, S.Q.; Huang, G.H.; Li, Y.P. An integrated scenario-based multi-criteria decision support system for Water Resource Management and planning-A case study in the Haihe River Basin. Exp. Syst. Applicat. 2010, 37, 8242-8254. [CrossRef]

150. Dowlatabadi, N.; Banihabib, M.E.; Roozbahani, A.; Randhir, T.O. Enhanced GMCR model for resolving conflicts in a transboundary wetland. Sci. Total Environ. 2020, 744, 140816. [CrossRef] [PubMed]

151. Väntänen, A.; Marttunen, M. Public involvement in multi-objective water level regulation development projects-evaluating the applicability of public involvement methods. Environ. Impact Assess. Rev. 2005, 25, 281-304. [CrossRef]

152. Wang, L.; Li, X.; Cui, W. Fuzzy neural networks enhanced evaluation of wetland surface water quality. Int. J. Comp. Applicat. Technol. 2012, 44, 235-240. [CrossRef]

153. Wolf, A.T.; Kramer, A.; Carius, A.; Dabelko, G.D. Managing Water Conflict and Cooperation, State of the World 2005: Redefining Global Security; The Worldwatch Institute: Washington, DC, USA, 2005; pp. 80-95.

154. de Castro-Pardo, M.; Pérez-Rodríguez, F.; Martín-Martín, J.M.; Azevedo, J.C. Planning for Democracy in Protected Rural Areas: Application of a Voting Method in a Spanish-Portuguese Reserve. Land 2019, 8, 145. [CrossRef]

155. Nordström, E.M.; Eriksson, L.O.; Öhman, K. Integrating multiple criteria decision analysis in participatory forest planning: Experience from a case study in northern Sweden. For. Policy Econ. 2010, 12, 562-574. [CrossRef]

156. Alamanos, A.; Mylopoulos, N.; Loukas, A.; Gaitanaros, D. An integrated multicriteria analysis tool for evaluating water resource management strategies. Water 2018, 10, 1795. [CrossRef]

157. Papaioannou, G.; Vasiliades, L.; Loukas, A. Multi-criteria analysis framework for potential flood prone areas mapping. Water Resour. Manag. 2015, 29, 399-418. [CrossRef]

158. De Marchi, B.; Funtowicz, S.O.; Lo Cascio, S.; Munda, G. Combining participative and institutional approaches with multicriteria evaluation. An empirical study for water issues in Troina, Sicily. Ecol. Econ. 2000, 34, 267-282. [CrossRef]

159. Srinivasa Raju, K.; Duckstein, L.; Arondel, C. Multi-criteria analyses for sustainable water resources planning: A case study of Spain. Water Resour. Manag. 2000, 14, 435-456. [CrossRef]

160. Hämäläinen, R.; Kettunen, E.; Marttunen, M.; Ehtamo, H. Evaluating a framework for multi-stakeholder decision support in water resource management. Group Decis. Negot. 2001, 10, 331-353. [CrossRef]

161. Pavlikakis, G.E.; Tsihrintzis, V.A. Integrating humans in ecosystem management using multi-criteria decision making. J. Am. Water Resour. Assoc. 2003, 39, 277-288. [CrossRef]

162. Mustajoki, J.; Hämäläinen, R.P.; Marttunen, M. Participatory multicriteria decision analysis with Web-HIPRE: A case of lake regulation policy. Environ. Model. Softw. 2004, 19, 537-547. [CrossRef]

163. Raju, K.S.; Duckstein, L. Integrated application of cluster and multicriterion analysis for ranking water resources planning strategies: A case study in Spain. J. Hydroinform. 2004, 6, 295-307. [CrossRef]

164. Wattage, P.; Mardle, S. Stakeholder preferences towards conservation versus development for a wetland in Sri Lanka. J. Environ. Manag. 2005, 77, 122-132. [CrossRef]

165. Messner, F.; Zwiner, O.; Karkuschke, M. Participation in multi-criteria decision support for the resolution of a water allocation problem in the Spree River Basin. Land Use Policy 2006, 23, 63-75. [CrossRef] 
166. Wang, L.; Meng, W.; Guo, H.; Zhang, Z.; Liu, Y.; Fan, Y. An interval fuzzy multiobjective watershed management model for the Lake Qionghai Watershed, China. Water Resour. Manag. 2006, 20, 701-721. [CrossRef]

167. Goosen, H.; Janssen, R.; Vermaat, J.E. Decision support for participatory wetland decision-making. Ecol. Eng. 2007, 30, 187-199. [CrossRef]

168. Marchamalo, M.; Romero, C. Participatory decision-making in land use planning: An application in Costa Rica. Ecol. Econ. 2007, 63, 740-748. [CrossRef]

169. Srdjevic, B. Linking analytic hierarchy process and social choice methods to support group decision making in water management. Decis. Supp. Syst. 2007, 42, 2261-2273. [CrossRef]

170. Hajkowicz, S.; Higgins, A. A comparison of multiple criteria analysis techniques for water resource management. Eur. J. Operat. Res. 2008, 184, 255-265. [CrossRef]

171. Van Cauwenbergh, N.; Pinte, D.; Tilmant, A.; Frances, I.; Pulido-Bosch, A.; Vanclooster, M. Multi-objective, multiple participant decision support for water management in the Andarax catchment, Almeria. Environ. Geol. 2008, 54, 479-489. [CrossRef]

172. Chung, E.S.; Lee, K.S. Prioritization of water management for sustainability using hydrologic simulation model and multicriteria decision making techniques. J. Environ. Manag. 2009, 90, 1502-1511. [CrossRef]

173. Ryu, J.H.; Palmer, R.N.; Jeong, S.; Lee, J.H.; Kim, Y.O. Sustainable Water Resour. Manag. in a Conflict Resolution Framework 1. J. Am. Water Resour. Assoc. 2009, 45, 485-499. [CrossRef]

174. Calizaya, A.; Meixner, O.; Bengtsson, L.; Berndtsson, R. Multi-criteria decision analysis (MCDA) for integrated Water Resour. Manag. (IWRM) in the Lake Poopo Basin, Bolivia. Water Resour. Manag. 2010, 24, 2267-2289. [CrossRef]

175. Chen, Y.C.; Lien, H.P.; Tzeng, G.H. Measures and evaluation for environment watershed plans using a novel hybrid MCDM model. Exp. Syst. Applicat. 2010, 37, 926-938. [CrossRef]

176. Silva, V.B.; Morais, D.C.; Almeida, A.T. A multicriteria group decision model to support watershed committees in Brazil. Water Resour. Manag. 2010, 24, 4075-4091. [CrossRef]

177. Yilmaz, B.; Harmancioglu, N. Multi-criteria decision making for water resource management: A case study of the Gediz River Basin, Turkey. Water SA 2010, 36. [CrossRef]

178. Chen, V.Y.; Lien, H.P.; Liu, C.H.; Liou, J.J.; Tzeng, G.H.; Yang, L.S. Fuzzy MCDM approach for selecting the best environmentwatershed plan. Appl. Soft Comput. 2011, 11, 265-275. [CrossRef]

179. Lennox, J.; Proctor, W.; Russell, S. Structuring stakeholder participation in New Zealand's water resource governance. Ecol. Econ. 2011, 70, 1381-1394. [CrossRef]

180. Aznar, J.; Estruch-Guitart, V.; Vallés-Planells, M. Valuation of environmental assets by the multicriteria AMUVAM method and its application to the Pego-Oliva wetland. Environ. Eng. Manag. J. 2014, 13, 597-610.

181. Pinto, R.; da Conceição Cunha, M.; Roseta-Palma, C.; Marques, J.C. Mainstreaming sustainable decision-making for ecosystems: Integrating ecological and socio-economic targets within a decision support system. Environ. Process. 2014, 1, 7-19. [CrossRef]

182. Aher, S.; Shinde, S.; Guha, S.; Majumder, M. Identification of drought in Dhalai River watershed using MCDM and ANN models. J. Earth Syst. Sci. 2017, 126, 21. [CrossRef]

183. Sheikhipour, B.; Javadi, S.; Banihabib, M.E. A hybrid multiple criteria decision-making model for the sustainable management of aquifers. Environ. Earth Sci. 2018, 77, 712. [CrossRef]

184. DasGupta, R.; Hashimoto, S.; Okuro, T.; Basu, M. Scenario-based land change modelling in the Indian Sundarban delta: An exploratory analysis of plausible alternative regional futures. Sustain. Sci. 2019, 14, 221-240. [CrossRef]

185. Everard, M.; Kangabam, R.; Tiwari, M.K.; McInnes, R.; Kumar, R.; Talukdar, G.H.; Das, L. Ecosystem service assessment of selected WETs of Kolkata and the Indian Gangetic Delta: Multi-beneficial systems under differentiated management stress. Wetlands Ecol. Manag. 2019, 27, 405-426. [CrossRef]

186. Hosseini, S.M.; Parizi, E.; Ataie-Ashtiani, B.; Simmons, C.T. Assessment of sustainable groundwater Resour. Manag. using integrated environmental index: Case studies across Iran. Sci. Total Environ. 2019, 676, 792-810. [CrossRef] [PubMed]

187. Kacem, H.A.; Fal, S.; Karim, M.; Alaoui, H.M.; Rhinane, H.; Maanan, M. Application of fuzzy analytical hierarchy process for assessment of desertification sensitive areas in North West of Morocco. Geocarto Int. 2019, 7, 1-18. [CrossRef]

188. Karabulut, A.A.; Udias, A.; Vigiak, O. Assessing the policy scenarios for the Ecosystem Water Food Energy (EWFE) nexus in the Mediterranean region. Ecosyst. Serv. 2019, 35, 231-240. [CrossRef]

189. Yun, H.J.; Kang, D.J.; Kim, D.K.; Kang, Y. A GIS-Assisted Assessment and Attribute-Based Clustering of Forest Wetland Utility in South Korea. Sustainability 2019, 11, 4632. [CrossRef] 